\title{
Groundwater in Egypt Issue: Resources, Location, Amount, Contamination, Protection, Renewal, Future Overview
}

\author{
H. I. Abdel-Shafy and Aziza H. Kamel \\ Water Research \& Pollution Control Department, National \\ Research Center, Cairo, Egypt.
}

\begin{abstract}
7 HE PRESENT review is concerning with the groundwater issue in Egypt. Groundwater is one of the most important resources of water in Egypt. It ranks as the second source after the Nile River. In addition, there are different groundwater aquifers with variable importance for exploitation in the Nile river region. They are ranging from shallow local aquifers, recharged by rainfall, to deep nonreplenishable aquifers. The first comprises groundwater in the Nile Valley and Delta system. The second aquifer category is the nonrenewable type, which is located in the "Western Desert-Nubian Sandstone Aquifer". Non-renewable groundwater exploitation is estimated at a rate of 1.65 Billion $\mathrm{m}^{3} /$ year $(\mathrm{BCM} / \mathrm{year})$. It is mainly concentrated at the Western Desert Oases with $0.5 \mathrm{BCM} / \mathrm{yr}$. On the other side, the amount of groundwater abstractions in Delta, Sinai and New Valley are about 5.1 BCM/yr. It is estimated that about 200,000 $\mathrm{BCM}$ of fresh water are stored in the New Valley's Oasis aquifer only. The water is at the depth of 60-100 $\mathrm{m}$ around the area of East-Oweinat. In Sinai, groundwater is mainly encountered in three different waterbearing aquifers. Further information concerning groundwater issue in Egypt, locations, origin, amount, quality and quantities, contamination, natural aquifer treatment, protection, uses, future overview and conclusion are included and discussed in details in this review.
\end{abstract}

Keywords: Groundwater, Egypt, Water resources, Location of groundwater, Amount of groundwater, Groundwater contamination, Groundwater protection, Groundwater renewable, Future overview and Issue of groundwater.

The survival of our human-race depends essentially on the ability to manage our natural resources, protect them from deterioration and utilizing such resources as efficiently as possible. Water; as an example; is one of the highest important natural resources that affect all the aspects of development in human life. Egypt has limited share of water. The main source is the Nile River. In the view of the rapid increase in population in Egypt, it has become imperative to maintain and protect the available water resources from pollution. The Egyptian Government and regulations, in cooperation with legislative bodies, has adopted several laws and limitation for the protection of waterways for the purpose of and to safeguard the water quality. 
During the last few decades, many countries world wide are concerned already with water scarcity. As a result, exploitation of marginal water resources has become a necessity in recent years. Municipal and sewage wastewater recycling is an important component of marginal resources. Recycled water is used; in many countries; for irrigation, urban and industrial needs in addition to indirect human water supply including flushing, land reclaimation, etc....

Middle East and North African (MEDA) countries can be taken as an typical example of a regions that is suffering from water deficit. Irrigation is in stingent needs in these countries where it is seasonal with peak values during spring and summer. Tourist activities are at its maximum during the same period, thus entailing an increase of potable water is in demand. Water resources, like springs and alluvial aquifers are highly depending on rainfall and is virtually needed during the summer season. As a result, fresh water supply often experiences great shortages in dry season. Therefore, seasonal imbalances between water resources and demands threaten the economy of many countries. Therefore, it is necessary to find out solutions for mitigating water deficit. Meanwhile, climatic variations, with consecutive dry years have led to severe droughts. These problems have to be faced resorting to emergency solutions such as shipping water from regions better provided with water resources as well as seawater desalination.

Variable water resources in Egypt are limited mainly to the Nile River, rainfall and groundwater reservoirs. The later is important in the deserts and Sinai. In 1966, renewable water resources in Egypt presented $2189 \mathrm{~m}^{3} /$ capita/yr. Presently, Egypt water resources went down to around $670 \mathrm{~m}^{3} / \mathrm{capita} / \mathrm{yr}$. This is mainly due to the continuous annual increase in population at the rate of $2.2 \%$. Therefore, the demands for freshwater resources are exerting excessive pressure on the available water supply. As Egypt is faced with these challenges, there is an urgent need to improve the efficiency of water consumption, and to augment the existing water sources with more sustainable alternatives. Numerous approaches are suggested for efficiency improvements. These approaches include mainly wastewater treatment / reuse and groundwater resources management ${ }^{(1)}$.

Groundwater plays an essential role in global drinking water supply. In Egypt, fresh groundwater resources contribute to less than $20 \%$ of the total potential of water resources ${ }^{(2)}$. Groundwater resources management provides solution against decline in other water sources, specially, in areas where aridity is increasing. In the present issue, we are going to discuss groundwater resources in Egypt, their location, origin, amount, the effect of wastewater reuse on groundwater contamination, natural groundwater aquifer, groundwater quality and quantities, protection of groundwater against rarity and contamination and finally uses and future overview.

Future of water resources in Egypt

Present Egypt population is over 91 million. The water availability per capita at present is about $650 \mathrm{~m}^{3}$ per year. The expected population of Egypt in 2025

Egypt. J. Chem. 59, No.3 (2016) 
will increase up to about 105 million, leading to a decrease in per capita water availability to scarcity of water assuming that total water availability remains the same constant.

Developments in riparian countries to Egypt including Ethiopia and Sudan could reduce water availability to Egypt. This development could be; for example; through increasing the abstractions for irrigation. Particular problem is the construction of the Ethiopian Dam that will need about 70 BCM of Nile water storage in the Dam. On the other hand, these countries could also increase water availability to Egypt through the draining of swamps. For example Sudd swamp in Ethiopia has large amounts of water that is currently exposed to extensive evaporation.

\section{Groundwater resources}

Groundwater aquifers have long played a key role in the attenuation of seasonal variations concerning the water demand. They constitute natural reservoirs, replenished during rainy periods, where a big quantity of water is stored and can be extracted to meet the dry period needs. However, as the water demand has dramatically increased over the years, aquifers have been overexploited, leading to severe depletion and salt water encroachment in coastal aquifers. In many places, aquifer water supply is no more sustainable. On the other hand, recycled wastewater is available all the year long. In rainy season, conventional water sources meet the demand and recycling water would be unnecessary and costly. When water demand is low, storing the recycled water in aquifers should take place and to be available to meet dry season needs. Artificial recharge of aquifers with recycled water is also used to control sea water intrusion in coastal areas.

Egypt is an arid country in North-East Africa, but has a large hydro-geologic potential with many groundwater aquifers widely distributed throughout the country. Groundwater is one of the most important resources of water in Egypt. The quality of groundwater depends on two main factors, namely, the origin of the water and the type of the bearing rocks. Also, the movement and the flow of water from one point to another are important factors. The major feeding sources of renewable groundwater are rainwater seepage, irrigation water and sanitary drainage water and industrial effluents. Thus, the quality of groundwater is greatly affected by surface activities as well as the type of water that feeds underground reservoirs ${ }^{(3)}$.

Aquifers are underground geological formation or group of formations containing usable amounts of groundwater. They are complicated heterogeneous, multi-layered systems, with boundaries often not well identified. Reliable predictions of groundwater flow is possible only if the aquifer system is well known. This means that enough data should be collected in order to allow working out well calibrated hydrodynamic numerical models. Flow patterns are relatively easy to predict and control in granular media aquifers. It is quite different with fractured rocks and karstic formations, where, despite recent improvements, modelling solute transfer is and will long remain difficult to achieve ${ }^{(4)}$. 
When better sources or high quality of water are not available, groundwater extracted from aquifers that was previously recharged with recycled water can be an option for potable water supply. Such practice, have brought the quality of the recycled water up to the most stringent potable water standards. However, this kind of drinking water is not accepted easily by the public. Injecting the treated wastewater followed by their recovering after few months later, mixed with natural groundwater, could be more accepted by consumers. In this case, the aquifer serves as a storage. It also serves as much more psychologically accepted and as an aesthetic facilitator.

Aquifer recharge could be acheived via direct or indirect. Direct recharge is to introduce the water directly to the aquifer into the injected wells. In this case the injected water must be adequetly treated to avoid any clogging of the aquifer, particularly, around the area of injection. On the other hand, indirect recharge is feasible for the unconfined aquifers only. Generally, the recharge water could be spread on the land (i.e. over-irrigation or over infiltration basins). The water then infiltrates down through the vadose zone until it reached the water table. The top unsaturated layer; thus, behaves as a filter or as a natural reactor. Such layer provides an additional treatment and it allows the quality of the percolating water to be highly improved.

In Egypt, the majority of aquifers are generally formed of either unconsolidated or consolidated granular (sand and gravel) material or in fissured and karstified limestone. These aquifers are unconfined or semi-confined aquifers. There are different groundwater aquifers with different importance for exploitation in the Nile River region. They range from shallow local aquifers, recharged by rainfall, to deep aquifers, which contain non-replenishable reserves being exploited on a large scale ${ }^{(3,5)}$.

Aquifer yield differs according to their nature. There are three types of aquifers: fractured-bedrock, weathered-mantle and fluvial aquifers. The highest yielding aquifers are the fractured bedrock. They are, usually, connected to an overlying layer of loose rocks covering the solid bedrock. Although such layers are low in permeability, they provide some degree of storage and replenishment. Bedrock may experience subsurface weathering at the upper boundary, forming saprolite. The weathered aquifer and the fractured-bedrock aquifer form two-layered aquifer system $^{(6)}$. Poorly weathered aquifers are capable of producing groundwater, often suitable for livestock. Deep weathering causes the formation of many secondary minerals, uranium and heavy metals in residual accumulations ${ }^{(7)}$. Alluvial and fluvial aquifers are those found adjacent to major surface water courses. These aquifers are found at relatively shallow depths, as in the case of Nile aquifer ${ }^{(8)}$.

\section{Classification of groundwater resources}

In Egypt groundwater can be classified into two categories:

Renewable groundwater resources:

Located in the Nile Valley and Delta system.

Egypt. J. Chem. 59, No.3 (2016) 
Non-renewable groundwater resources:

Located in the Nubian Sandstone Aquifer at the Western Desert ${ }^{(2)}$.

Locations of groundwater in Egypt

The main underground reservoirs in Egypt:

1. Nile aquifer

This covers the Nile Valley region, Delta and the adjacent desert edges, representing about $4 \%$ of the area in Egypt.

2. Nubian Sandstone aquifer

Located mainly in the Western Desert, parts of Eastern Desert and Sinai Peninsula. It supplies the New Valley's Oasis with groundwater.

3. Moghra aquifer

Covering the desert area at the edge of the West Delta.

4. Coastal aquifer $\left(20,000 \mathrm{~km}^{2}\right)$

Located on the North-Western and the Eastern coast.

5. Fissured Carbonate aquifer

Located essentially in the North and middle region of the Western Desert. It covers an area of about $500,000 \mathrm{~km}^{2}$, presenting more than $50 \%$ of Egypt area.

6. Pre-Cambrian Fissured and weathered hard rock aquifer

Predominating in the Eastern Desert and Sinai and underlying the Nile Delta ${ }^{(2,3,8)}$.

7. Groundwater in Sinai ${ }^{(2,9)}$

8. Groundwater in the Western Nile Delta aquifers ${ }^{(3)}$.

The main aquifers in Egypt are shown in Fig. 1.

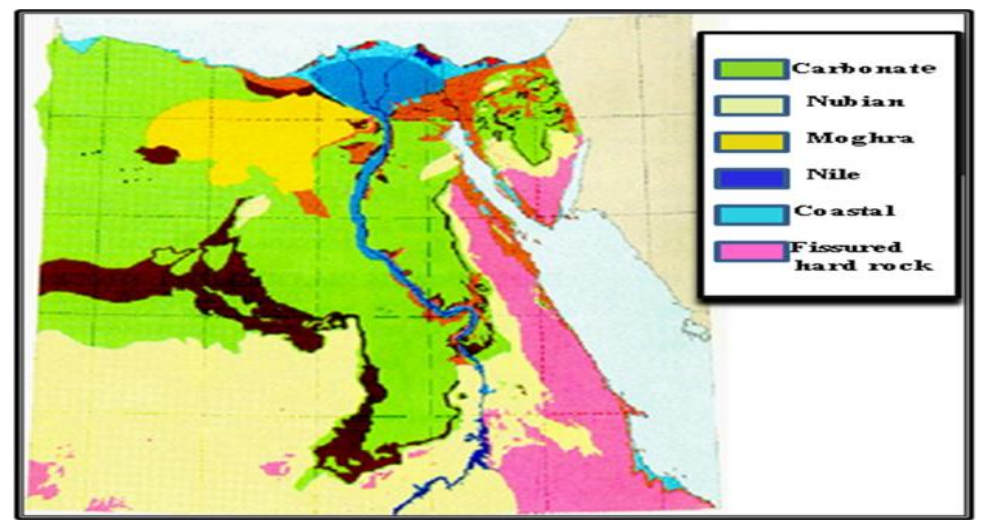

Fig. 1. Main groundwater aquifers in Egypt.

Amount of groundwater in Egypt

The annual groundwater abstraction in the Nile aquifer system is about 4.6 BCM. The total groundwater abstraction in Delta, Sinai and New Valley is estimated to be $5.1 \mathrm{BCM} /$ year. On the other side, $0.5 \mathrm{BCM} /$ year is abstracted 
from the western desert aquifers ${ }^{(1,3)}$. The Nile valley aquifer is; by far; the largest followed by the Nubian then the Moghra aquifer. Sinai aquifer is; relatively; the smallest one. Distributions of the main location of the groundwater abstraction are shown in Fig. 2.

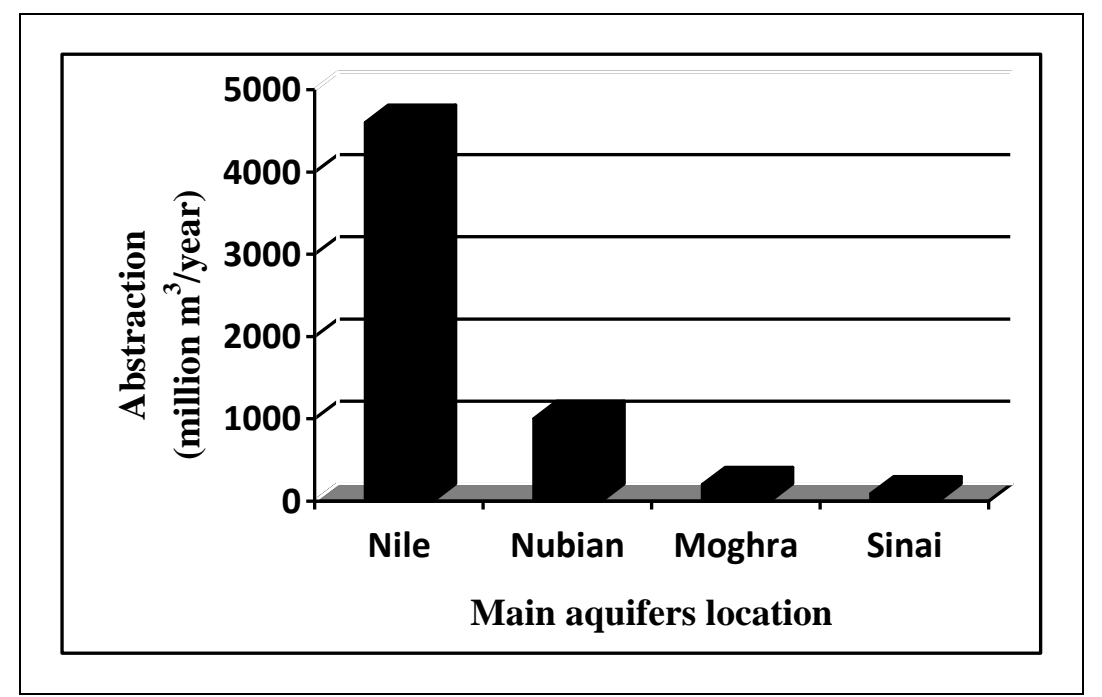

Fig. 2. Distribution of groundwater abstraction in the main aquifers (million $\mathrm{m}^{3} / \mathrm{year}$ ).

\section{Description and exploitation of Egyptian main aquifers}

1. The Nile aquifer dating back to the Quaternary and Late Tertiary ${ }^{(3)}$ : It is not a resource in itself, as it is replenished from the Nile River by seepage from canals and deep percolation as a result of flood irrigation. It is a renewable source with high productivity. The total storage capacity of the Nile Valley aquifer system is about 200 BCM. The storage capacity of the Delta aquifer is about 300 BCM. It occupies the Nile flood plain in the Nile proper, as well as in the Delta, consisting of fluvial sediments. The sediments are covered by clay cap of varying thickness up to $50 \mathrm{~m}$ in the northern part of Delta ${ }^{(2,8)}$.

2. The Nubian sandstone aquifer dating back to the Paleozoic-Mesozoic ${ }^{(3)}$ : It is of fossil origin. It has been estimated that the total volume of fresh water stored in this aquifer exceeds 150,000 BCM. The aquifer is phreatic in the southwestern part of Egypt. Elsewhere it is confined by a thick cover of carbonate rock (limestone). Its northern boundary is a fresh/salt water interface that follows a fault line north of Siwa oasis, crosses the Nile Valley between Minya and BeniSuef and bends further to north-East into Sinai ${ }^{(8)}$.

3. The Moghra aquifer dating back to the Lower or early Miocene: This aquifer, dominated by fluvio-marine sands, occupying a wide area located to the west of the Nile Delta. It is located west of the Cairo-Alexandria Desert Road

Egypt. J. Chem. 59, No.3 (2016) 
with an average thickness of $300 \mathrm{~m}$. Its thickness varies from a few tens of meters on the eastern side to almost $1000 \mathrm{~m}$ on the western side (i.e. in the vicinity of the Qattara and Sidi-Barrani). It is considered as a non-renewable aquifer system, although there are indications of hydraulic continuity with the Delta aquifer.

4. The Coastal aquifer located along the Mediterranean and the Red Sea coast: These aquifers are recharged by rainfall. They comprise water bearing formations consisting of coastal dunes and bars, wadi deposits, calcarenites and shallow marine sands, dating back to the Quaternary and to the late Tertiary. These formations occupy the north western and eastern coasts, including Mariut Area to the west of Alexandria. Local reservoirs, mainly geological structure origin of Tertiary and pre-Tertiary, are found in some locations along the Red Sea. They are found at Ayoun-Moussa and EL-Qaa in Sinai and also at Shagar, Safaga, Quseir, Ras-Peras and Halayib in the Eastern Desert ${ }^{(2)}$.

5. Fissured and weathered hard rock aquifer dating back to the PreCambrian: It is renewable, characterized by its high productivity and shallow depth, allowing the abstraction of large quantities of water $\left(100-300 \mathrm{~m}^{3} / \mathrm{h}\right)$ at low pumping $\operatorname{cost}^{(3)}$.

6. Groundwater in Sinai: In Sinai Groundwater is mainly encountered in three different water-bearing aquifers including:

1. The shallow aquifers in northern Sinai: the thickness of the aquifers varies between 30 and $150 \mathrm{~m}$.

2. The valley aquifers.

3. The deep aquifers.

The shallow aquifers in the northern part of Sinai are composed of sand dunes that hold the seasonal rainfall (heavy storms), which helps to fix these dunes. The annual rainfall on Sinai varies from $40 \mathrm{~mm}$ to $200 \mathrm{~mm} /$ year. Although most of the shallow aquifers are renewable, only 10 to $20 \%$ of the deep aquifers are renewable by rainfall and flash floods. The aquifers in the coastal area are subject to salt-water intrusion but groundwater salinity level could be treated to be used for irrigating certain crops. At Southern part of Sinai, there are several shallow and deep reservoirs that have a limited potential for development ${ }^{(2,9)}$.

7. Groundwater aquifers in the Western Nile Delta Region: The groundwater in this region forms a hydrological unit where water flows from an aquifer to another. The major-ions including $\left(\mathrm{Na}+\mathrm{K}+, \mathrm{Ca}^{2+}, \mathrm{Mg}^{2+}, \mathrm{Cl}^{-}, \mathrm{SO}_{4}{ }^{2-}, \mathrm{CO}_{3}{ }^{2-}\right.$ and $\mathrm{HCO}_{3}{ }^{-}$) as well as the trace elements namely: ( $\mathrm{Fe}, \mathrm{Mn}, \mathrm{Zn}, \mathrm{Cu}, \mathrm{Pb}, \mathrm{Cr}, \mathrm{Ni}$ and $\mathrm{Cd})$ are used to constrain the hydro chemical characteristics of this particular groundwater. The salinity varies widely from $430 \mathrm{mg} / \mathrm{L}$ (as freshwater) to 24,407 $\mathrm{mg} / \mathrm{L}$ (as saline water). The average of salinity is $2,705 \mathrm{mg} / \mathrm{L}$ (as brackish water). Fresh water is concentrated mainly in the eastern and central part of the region, close to Rosetta Branch. This indicates that the aquifer is mainly a recharge resulted from the infiltration of the irrigation activities as well as the excess of 
irrigation water through the upper soil layer (i.e. clay layer). Due to seawater intrusion, the salinity of this aquifer increases gradually north and westwards where it is mixed with the Miocene aquifer. The $\mathrm{pH}$ 's of this groundwater ranges from 7.11 to 8.65 with an average of 7.9 (i.e. it is slightly alkaline). The highest anion concentration are the chloride $\left(\mathrm{Cl}^{-}\right)$and sulfate $\left(\mathrm{SO}_{4}{ }^{2-}\right)$, while the highest cation concentration are the sodium $\left(\mathrm{Na}^{+}\right)$, calcium $\left(\mathrm{Ca}^{2+}\right)$ and magnesium $\left(\mathrm{Mg}^{2+}\right)$ in this aquifer. The major ions concentrations exceed the maximum standard limits that are recommended by the World Health Organization (WHO, 1996). The nutrient content namely, phosphates and nitrates are more than the maximum accepted limits. Such high nutrients concentration was recorded in the old cultivated lands, as an indication of irrigation with contaminated water.

On the other hand, the recorded concentrations of trace elements are lower than the standard limits except for nickel, manganese and iron. The hydrochemical composition could reflect the type of the aquifer. The $\mathrm{Na}-\mathrm{HCO}_{3}$ water is the type of (Quaternary) aquifer in the Delta that indicates recent meteoric water. On the other hand, the $\mathrm{Na}-\mathrm{Cl}$ water is the type that was recorded in the high salinity areas of northern and western parts. Furthermore, $\mathrm{Na}_{2}-\mathrm{SO}_{4}$ water type was also recorded that indicates deep meteoric genesis. With reference to the "U.S. Salinity Laboratory Diagram": ground-waters are mostly located in the high salinity and low sodium hazard zone. The ground-waters that are characterized by less than $1.25 \mathrm{meq} / \mathrm{L}$ of residual sodium carbonate (RSC) are classified as good quality of water and are suitable for irrigating all types of soils. In conclusion, the ground-waters are relatively shallow in depth. However, they are greatly affected by the different surface activities including: the rate of water withdrawal, irrigation canals and the use of chemical fertilizers. Therefore, it is recommended to use the groundwater resources carefully (i.e. without depending totally on it).

8. Nubian sandstone aquifer system (NSAS): It is a Fissured carbonate aquifer in reference to the Eocene - to the Upper Cretaceous. On the other hand, NSAS is the world's largest known fossil water aquifer. It is the underground aquifer in the Eastern end of the Sahara Desert located in the North-Eastern Africa. It spans through the political boundaries of 4 countries in this region. It is considered as a confining layer acts on the top of the Nubian Sandstone Aquifer. It is a thick layer of the carbonate limestone that excess $1000 \mathrm{~m}$. However, it varies in the thickness from one place to the other, ranging from $200 \mathrm{~m}$ at $\mathrm{El}$ Farafra Oasis to $900 \mathrm{~m}$ at Siwa Oasis. Meanwhile, brackish water occurs in various locations. It is considered as one of the poorest and least explored aquifers in Egypt.

This NSAS covers an area of more than two million $\mathrm{km}^{2}$. The area includes south-eastern Libya, north-eastern Chad, north-western Sudan, and most of west Egypt. It is estimated that this aquifer contains about $150,000 \mathrm{~km}^{3}$ of groundwater ${ }^{(2,3,8)}$. The importance of this NSAS as water resource is very promising for future development in these countries. By the end of the twentieth

Egypt. J. Chem. 59, No.3 (2016) 
century, the "Great River" the Man-made River in Libya began extracting substantial amounts of water from this aquifer. The Libyan "Great River" is the Manmade piping system in the Sahara Desert of Libya as huge network of pipes to supply water from the Nubian Sandstone Aquifer. It is the world's largest irrigation project (Fig. 3). The extraction is estimated $2.37 \mathrm{~km}^{3}$ per year. The extracted water is primarily used to supply the Kufra Oasis with water.

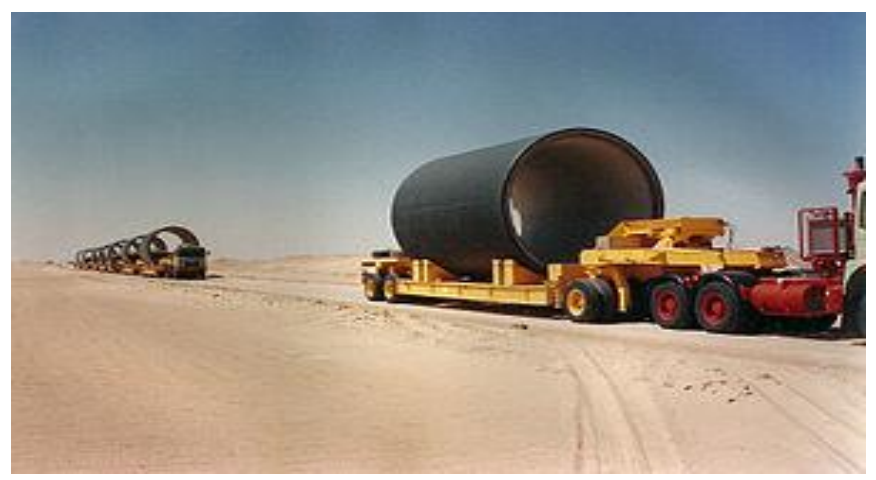

Fig. 3. the transport of pipe segments for the artificial "Great River" in Libya.

Characteristics of the NSAS : As part of a land reclamation project in Egypt, intensive drilling and development was going on; since 2001; in the area between the Toshka and Abu Simbel using the Nubian Sandstone aquifer. Drilling information was employed to carry out different studies concerning the hydrogeological setting of the area's aquifer. Results obtained showed that the tectonic settings and the litho logical characteristics poses a substantial effect on the patterns of groundwater flow and the overall aquifer area. However, this flow is considered; relatively; low in correlation to the neighboring areas in Dakhla Oasis or eastern Oweinat.

Geology of the NSAS : The NSAS aquifer is composed mostly of hard ferruginous sandstone with clay and great shale intercalation. The thickness ranges from 140 to 230 meters. Groundwater varies from fresh to slightly brackish type. As a result salinity varies from $240-1300 \mathrm{ppm}$. With respect to the ions in this groundwater, sodium cation is the most dominated one followed by calcium then magnesium. For anion: chloride is predominant followed by sulfate then bicarbonate. Groundwater in this aquifer is of meteoric origin ${ }^{(2,3)}$ (i.e. water is originated from rain precipitation as most of groundwater in the world). High concentration of chloride, sulfates and sodium, reflects both dissolution and leaching processes of gypsiferous clay and shale's. Another important factor is the lengthy duration of water residence in this aquifer ${ }^{(8)}$.

The International development projects of the Nubian sandstone aquifer (NSA) : Starting from 2006, the International Atomic Energy Agency (IAEA) 
has been cooperating with the four countries of NSAS, namely Libya, Egypt, Sudan and Chad to help increase understanding of the aquifer's complexities. The cooperation is through the IAEA-UNDP-GEF Nubian Project. The partners of the project include the United Nations Development Program (UNDP)/Global Environment Facility (GEF), United Nations Educational, Scientific and Cultural Organization (UNESCO), IAEA as well as the government representatives from the four NSAS countries. It is a long-term project aim to establish equitable and rational management of the NSAS in productive way and with regard to the socio-economic development in the mentioned region as well as protecting biodiversity and land resources ${ }^{(2,3,8)}$.

Origin of groundwater in Egypt

Recharge of groundwater

Recharge of groundwater in Nile Delta area takes place by different processes including:

- Infiltration of rainfall water

- Infiltration and downward leakage of excess irrigation water and leakage from canals; and

- Inter-aquifer flow of groundwater ${ }^{(3)}$.

Recharge of groundwater by rainfall : This type of recharge is negligible and takes place only during the winter seasons.

Infiltration : It occurs through seepage from surface water, especially from irrigation canals and subsurface drainage water in cultivated area ${ }^{(9-12)}$.

Inter-aquifer flow : It is a minor factor of recharge, which occurs from the Nile Delta towards the aquifers in the Western Nile Delta region.

\section{Discharge of groundwater}

It includes groundwater return flow to canals and drains ${ }^{(3)}$, direct extraction, evapo-transpiration and inter-aquifer flow of groundwater.

\section{Quality and quantity of groundwater}

There are several factors affecting groundwater quality and quantity including :

\section{The hydrologic and hydro-geologic controls}

It is important to have full knowledge of the hydrologic and hydro-geologic controls that govern the yields of aquifers and behavior of groundwater levels under abstraction stress. Minerals of watershed area are the primary process controlling the hydro-chemical processes such as cation exchanges, leaching, dissolution, evaporation and oxidation-reduction. Most influence on groundwater quality is leaching and dissolution of weathered rock. Moreover, this hydrochemical processes help to get an insight into the contributions of rock-water interaction influences on groundwater quality ${ }^{(13)}$. Furthermore, the weathering of primary and secondary minerals is also contributing cations and silica in the system $^{(14,15)}$. Silicate weathering is one of the keys for geochemical processes 
controlling the major ions chemistry of groundwater, especially in hard rock aquifers $^{(16-18)}$. The chemistry of groundwater chemically evolves by interacting with aquifer minerals or internal mixing among different groundwater along flow-paths in the subsurface ${ }^{(4,19)}$.

\section{Weathering}

Weathering is an important natural phenomena controlling water quality. Weathering is defined as the breaking down of rocks, soil and minerals as well as artificial materials through contact with several conditions such as: the Earth's atmosphere, biota and waters. It should not be confused with erosion, which involves the movement of rocks and minerals by agents including water, ice, snow, wind, waves and gravity and then being transported and deposited in other locations. Weathering is affected by the Characteristics of the parent material (rock soil and minerals), environmental conditions (temperature and moisture) and organism's activities.

There are five important classifications of weathering processes including:

2.1 Physical and chemical weathering : Sometimes, they involve a biological component.

2.2 Mechanical or physical weathering : Physical weathering is the breakdown of parent rock materials without chemical change. It involves the breakdown of rocks and soils through direct contact with atmospheric physical conditions, such as heat, water, ice and pressure.

2.3 Chemical weathering : Chemical weathering is the chemical change of rock and minerals under surface conditions. It involves the direct effect of atmospheric chemicals or biologically produced chemicals. It is also known as biological weathering on the breakdown of rocks, soils and minerals ${ }^{(20-22)}$.

It occurs when parent rock materials react with acidic or oxidizing substances, usually in the presence of water. Carbonic acid is the most important of these acids. It is formed through the reaction of $\mathrm{CO}_{2}$ (produced by respiration of plants, soil animals, and microbes) with water. During chemical weathering, primary minerals, present in the rock, dissolve, releasing ions and forming secondary minerals. Chemical reactions are more intense where the climate is wet and hot. Temperature speeds chemical reactions and enhances microbial and plants activities. The various agents act together to convert primary minerals (feldspars and micas) to secondary minerals (clays and carbonates), releasing plant nutrient. For example, physical weathering decreases the size of particles and therefore increases their surface area, making them more susceptible to rapid chemical reactions. The materials left over after the rock breaks down combined with organic material creating soil. The mineral content of the soil is determined by the parent material, thus a soil derived from a single rock type can often be deficient in one or more minerals for good fertility, while a soil weathered from a mix of rock types (as in glacial, aeolian or alluvial sediments) often makes more fertile soil. 
Meanwhile, "Salt crystallization" may also take place when solutions decompose rocks (for example, limestone and chalk) to form salt solutions, of which the moisture evaporates to form their respective salt crystals. The salts which have proved most effective in disintegrating rocks are sodium sulfate, magnesium sulfate, and calcium chloride. Some of these salts can expand up to three times or even more. It is normally associated with arid climates (as in Egypt) where strong heating causes strong evaporation and therefore salt crystallization. It is also common along coasts.

2.4 Biological weathering : Organisms activities affect weathering the same as Chemicals affect organism's activities

The most common forms of biological weathering are the release of chelating compounds (i.e. organic acids, siderophores) and of acidifying molecules (i.e. protons, organic acids) by plants, so as to break down aluminum and iron containing compounds in the soils beneath them. Decaying remains of dead plants in soil may form organic acids which, when dissolved in water, cause chemical weathering ${ }^{(22)}$. Extreme release of chelating compounds can easily affect surrounding rocks and soils, and may lead to podsolisation of soils ${ }^{(23)}$.

A number of plants, animals and microorganisms may create chemical weathering through release of acidic compounds, as previously described. For example, the effect of moss growing on roofs is classed as weathering. Mineral weathering can also be initiated and/or accelerated by soil microorganisms. Lichens on rocks are thought to increase chemical weathering rates. For example, an experimental study on hornblende granite in New Jersey, USA, demonstrated 3 times to 4 times increase in weathering rate under lichen covered surfaces compared to bare rock surfaces ${ }^{(24)}$.

The symbiotic mycorrhizal fungi associated with tree root systems can release inorganic nutrients from minerals such as apatite or biotite and transfer these nutrients to the trees, thus contributing to tree nutrition ${ }^{(25)}$.

2.5 Microbiological weathering : Mineral weathering by bacteria plays an important role $^{(26)}$. It was recently evidenced that bacterial communities can impact mineral stability leading to the release of inorganic nutrients ${ }^{(27)}$.

2.6 Properties of well-weathered soils : Three groups of minerals often remain in well-weathered soils: silicate clays, very resistant end products including iron and aluminum oxide clays, and very resistant primary minerals such as quartz. In highly weathered soils of humid tropical and subtropical regions, the oxides of iron and aluminum, and certain silicate clays with low $\mathrm{Si} / \mathrm{Al}$ ratios are predominated because most other constituents are broken down and removed ${ }^{(22)}$.

\section{Groundwater salinity}

The salinity of groundwater in Egypt ranges between 200 to 12,000 ppm. It is normally less than $1,500 \mathrm{ppm}$, at the Nile Valley aquifer. The salts' concentration depends on the location of the reservoir as well as the type of water-bearing rocks ${ }^{(2)}$.

Egypt. J. Chem. 59, No.3 (2016) 
Salinity levels of the groundwater have increased in the Nile basin. This salinity increases at the desert fringes of the Nile Valley. This may be caused by leaching of natural salts and partly by application of gypsum to the soil. High concentrations of manganese, iron and sulphate are recorded, which may be due to reduction and dissolution processes ${ }^{(8)}$.

The interpretation of the monitoring results, conducted by the Ministry of Water Resources and Irrigation in the Nile Valley underground reservoir during 2004, indicates a slight rise in the concentrations of iron and manganese elements in the Baraqshah Region of El-Minia Governorate, exceeding the permissible levels for potable water in conformity with the World Health Organization standards ${ }^{(28,29,30)}$. Coliform bacterial pollution was also detected in the shallow domestic wells due to the ad hoc drainage of sanitary drainage water, without complying with the sound conditions and precautions that are required while constructing domestic sanitary drainage pits. The monitoring results show also that deep wells are not polluted with bacteria. Groundwater resources in Egypt still need more programs to develop those resources and optimize their utilization. The Law on "Irrigation and Drainage Number 12/1984" is presently being amended, concentrating on groundwater licensing, the bases of safe use, the procedures for conservation and imposing more strict penalties on violators ${ }^{(31)}$.

Moreover, all major aquifer systems in Egypt contain vast quantities of brackish groundwater.

- In Coastal aquifer system as Mariut area to the west of Alexandria: The salinity of water is affected by seawater intrusion and is generally in excess of $2000 \mathrm{ppm}$. The excess water in the land reclamation projects, contributes to the recharge of the brackish water ${ }^{(2)}$.

- In the Eastern Desert and Sinai: Groundwater shows high salinity ${ }^{(8)}$. At Sinai, salinity is varying from $2000 \mathrm{ppm}$ up to $9000 \mathrm{ppm}$, presenting one of the highest salinity in $\mathrm{Egypt}^{(2)}$. At northwest Sinai, groundwater is heavily contaminated due to excessive use of fertilizers and pesticides. The concentrations of nitrates, sulfates and phosphates are high. More than $71.2 \%$ of the studied area has nitrate concentration values greater than $44.29 \mathrm{mg} / \mathrm{L}$, representing a serious problem ${ }^{(32)}$. Groundwater pollution sources were represented by waste disposal and agricultural activities, as well as saltwater intrusion. Pollution risk is high when the depth of the water table is shallow $(0.3$ to $15.0 \mathrm{~m})$ and the aquifer has high hydraulic conductivity and poor matrix buffering capacity ${ }^{(33)}$.

- In El-Moghra aquifer, located west of the Cairo-Alexandria Desert Road: The brackish water in this aquifer occupies a wide belt to the west of Wadi-ElFarigh and Wadi-El-Natrun and the water changes to saline and hyper saline further to the west. Associated with El-Moghra aquifer, there is a localized aquifer in the Pliocene beds, known as Wadi-El-Natrun aquifer. It is generally brackish (salinity $>1000 \mathrm{ppm}$ ) and is fed mainly by lateral seepage from the Delta aquifer and from upward leakage from the El-Moghra ${ }^{(2)}$.

Egypt. J. Chem. 59, No.3 (2016) 
- In Western Nile Delta aquifers: Irrigation requirements have become so large that they cause depletion of the groundwater levels in most of the existed wells. The groundwater is slightly alkaline with $p H$ 's ranging from 7.11 to 8.65. The salinity of the groundwater as a total dissolved solid (TDS) ranges from 430 $\mathrm{mg} / \mathrm{L}$ (freshwater) in some parts of the Quaternary aquifer to $24,407 \mathrm{mg} / \mathrm{L}$ (saline water) in the northwestern Nile Delta, with an average of 2,705 mg/L (brackish water). It increases gradually north- and westwards due to seawater intrusion and mixing with the El-Mohgra aquifer, respectively. Several conducted studies showed that the concentrations of the major ions are higher than the maximum standard limits, according to the World Health Organization ${ }^{(28-30)}$. Sodium chloride is recorded in the high salinity areas of northern and western parts. The hydro-chemical composition reflects the $\mathrm{Na}-\mathrm{HCO}_{3}$ water type for the Quaternary aquifer, although water is suitable for using in irrigation ${ }^{(34-36)}$.

- In the Western Desert, especially in the Nubian sandstone : Iron concentration shows high levels. At Kharga and Dakla, the salinity decreases with depth, from $1000 \mathrm{ppm}$ in the upper layer to $200 \mathrm{ppm}$ in the deepest Layer. At Siwa, fresh water salinity ranges from 200 to $400 \mathrm{ppm}$ at the upper layer only, while deeper layers contain hypersaline water. At Bahariya Oasis, groundwater salinity varies between 190 and 410 ppm.

- In Fissured Carbonate aquifers : Brackish water is found in various locations. Fresh water is found only in areas where the aquifer is recharged ${ }^{(8)}$. Salinity ranges from about 1000 to $12000 \mathrm{ppm}$. However, the estimate of exploitable brackish water in the fissured carbonates is in the order of 5 billion $\mathrm{m}^{3}$.

Uses for brackish groundwater include agriculture (salt tolerant crops) and fisheries (shrimp farms). Desalination of brackish groundwater in Egypt has a great potential. The elements of the vision for desalination of brackish groundwater are: environmental sustainability through recycling of water and re-infiltration ${ }^{(2)}$.

4. Effect of the physical properties of aquifers on the quality of groundwater

The physical properties of an aquifer affect groundwater contamination. For example, unconfined aquifers are more exposed to contamination than confined aquifers, as they are usually nearer to land surface and lack an overlying confining layer to inhibit the movement of contaminants.

\section{Interaction of surface and groundwater}

Interaction of surface and groundwater, as well as changes in flow and recharge rates are also important considerations to determine groundwater quality and quantity. For example, in multi-aquifer systems coastal areas, sea intrusion may affect groundwater quality. In a study conducted at Western north coastal aquifer, the fresh-salt water interface affecting the water table was studied ${ }^{(36)}$. The rate of flow from this aquifer to the sea was found to be $1.5 \mathrm{~m}^{3} /$ day and the hydraulic conductivity was $12.8 \mathrm{~m} /$ day.

Egypt. J. Chem. 59, No.3 (2016) 
Costal aquifers in Egypt includes:

1- Western North Coastal Aquifer.

2- Alexandria Coastal Aquifer.

3- Eastern North coastal Aquifer (El-Abd well in Romana Region).

4- El-Arish-Rafah Aquifer.

5- Western North Coastal Aquifer of El-Akaba Gulf (Noweiba, Dahab and Sharm-El-Sheikh).

6- Red Sea Coastal (El-Zafrana and Halayeb) ${ }^{(3)}$.

\section{Groundwater contamination}

When pollutants are introduced with the recharge water, they will either move with the water, as nitrates do, or they are removed and retained on the solid phase. Removed pollutants, if not degraded, accumulate within the aquifer. Pollutants removal is regarded as a positive impact. Despite very promising findings, uncertainties remain on the fate of these contaminants. Does a risk exist that they appear in the abstracted water due to changes in the physical-chemical conditions prevailing into the aquifer or to limited adsorption capacities. How long microorganisms are able to survive? To what extent toxic pollutants are degraded? The most attractive aquifers for recharge projects are large aquifers allowing long term storage and long water retention time. This long retention time is viewed as an advantage, favouring contaminant removal. On the other hand, pollutant contamination may have a long term impact, particularly for those which are not subjected to efficient removal processes. Aquifer which has been polluted is difficult, long and expensive to reclaim; therefore, not risking to jeopardize groundwater resource is a pre-requisite of artificial recharge ${ }^{(37-41)}$.

Aquifers are exploited through a number of pumping wells, private and public, serving at the same time different purposes: public and private potable water supply, irrigation, industrial water, etc. Required water quality varies according to the different uses. Therefore, two options are offered. The first one is to plan and operate the recharge in order that the aquifer water quality meets the more stringent requirements or the aquifer water quality is not deteriorated. The second option is more sophisticated; it consists in a sector-based management. Different quality waters for different purposes are pumped in different areas. But, as an aquifer is a continuum, an in depth knowledge of the aquifer is required and a close monitoring of water quality should be performed. A sector-based management requires stakeholders agreement and a control of the withdrawals, making sure, for instance, that water fit only for irrigation is not pumped by farmers for potable water supply. The plume of injected water should be monitored through the contents in wastewater tracers. Furthermore, as retention times are long in the aquifers, the adopted exploitation policy can not be submitted to short term variations.

Aquifer recharge and contamination as affected by irrigation drainage infiltration

The most important aquifer in Egypt is the Nile aquifer system. The main recharge source is percolation from agriculture and infiltration from irrigation 
and drainage canals. Due to the interaction of groundwater with surface waters, pollution of aquifers is closely related to adjacent polluted surface waters. Pollution is more severe on the edges and desert fringes of the Nile Valley and in the shallow portions of the aquifers ${ }^{(42)}$. Contamination such as E. coli of $>100$ MPN/100 ml, and organ phosphorus and carbamate pesticides were observed at shallow depths in regions with highly contaminated groundwater. Meanwhile, organ chlorine pesticides were found at greater depths. Organ chlorine pesticides are characterized by their long persistence in the environment ${ }^{(9)}$. Nitrate, occasionally $70-100 \mathrm{mg} / \mathrm{L}$ is expected to increase with time in regions with intensive fertilizers application. High salinity was observed and ascribed to seawater intrusion and local return flow from irrigation. Natural iron and manganese were also noted ${ }^{(9,10,12,43)}$.

\section{Groundwater contaminants}

There are several sources that cause the groundwater contamination including :

1. 1. Trace elements : Trace elements are commonly present at low levels in nature. Many trace elements are essential micronutrients in very small quantities such as iron, manganese, molybdenum and zinc, but the range between deficiency and toxicity is narrow. Trace elements of concern in drainage water from irrigated lands include: arsenic, boron, cadmium, chromium, copper, lead, mercury, molybdenum, nickel, selenium, strontium, uranium, vanadium and zinc. The heavy metal trace elements are fixed strongly by soil materials and tend to be mobile only in the topmost soil layers. However, some of them form mobile metal-organic complexes in the presence of organic matter. Some trace elements (arsenic, selenium, molybdenum and uranium) are relatively immobile in the reduced form (precipitated or elemental) or are adsorbed, while the oxidized and oxyanion species are mobile. For example, selenium is soluble in alkaline and well-oxidized soils. In natural aquifers, arsenic is especially a problem in West Bengal, India, and Bangladesh. This is also reported in other countries ${ }^{(44)}$.

In Egypt, at Northwest Sinai, groundwater is heavily contaminated with major and minor trace elements ${ }^{(32,33)}$. In Western Nile Delta aquifers, the concentrations of the trace elements are lower than the standard limits ${ }^{(28)}$, except for iron, manganese and nickel ${ }^{(34)}$. A study conducted at the same area, showed high concentration of trace elements including iron and manganese ${ }^{(36)}$. Other study showed that water was generally of good quality, at most parts of the studied area ${ }^{(45)}$. The concentration of chromium, cadmium, lead and zinc were all within the permissible limits of drinking water quality ${ }^{(30)}$. At Bahariya Oasis, Western desert, dissolved iron and manganese from sedimentary formations are released to groundwater under reducing conditions. This natural process caused iron deposition, at Bahariya and Farafra Oases, causing clogging of wells ${ }^{(8)}$.

1. 2. Domestic wastewater: Wastewater reuse has several applications, primarily in agriculture, and additional areas, including industrial, household, and urban. Wastewater reuse for agriculture still represents the most important application, particularly in developing countries ${ }^{(46)}$. Other applications include

Egypt. J. Chem. 59, No.3 (2016) 
direct injection of treated wastewater into groundwater aquifers, which is utilized in several countries. This method requires advanced pretreatment of applied water, including sufficient disinfection. Without treatment, the injected wastewater may pollute the aquifer, causing health concerns ${ }^{(12,40,46)}$.

In Egypt, treated wastewater reuse is of tremendous potential importance. Effluents from municipalities have been used in sandy soil areas near Cairo, since 1992. Currently, treated wastewater is being used in irrigation of which 0.26 $\mathrm{BCM}$ is undergoing secondary treatment and $0.44 \mathrm{BCM}$ undergoing primary treatment ${ }^{(1)}$. The use of treated sewage water for irrigating the desert sandy soil in Egypt has been practiced in Cairo. Abu-Rawash Sewage Farm is one that was established in 1944. The farm is irrigated by the flood system. Seepage water beneath the irrigated land is a result of the continuous use of sewage irrigation. Such seepage water, or so-called "groundwater," is the only source for daily domestic use, including cooking, for the farmers who live there ${ }^{(12)}$. The use of treated wastewater in irrigation could have several effects as heavy metals accumulation in soil leading to nutrient disorders in plants and thus desertification $^{(47)}$. In addition, groundwater pollution resulting from infiltration of contaminated water source, may pose a problem. Consequently, rapid degradation in surface and groundwater quality were recorded, the result is less available water for different uses ${ }^{(10-12)}$.

In general, sanitation services in Egypt are less developed than water supply services. Meanwhile, the capacity of wastewater treatment plants has increased, at present ${ }^{(1,48)}$.

1. 3. Industrial wastes : "Efficient production causes lesser pollution". Cleaner production is defined by UNEP's Industry and Environment Program Activity Center as "the continuous application of an integrated preventive environmental strategy to reduce risks of processes and products to humans and the environment" ${ }^{\text {"(49) }}$. Inefficient production in some industries (e.g., oil and soap) generates waste that contains raw material, as well as products, a costly burden to the national economy and consumer.

Several studies revealed that untreated industrial wastewater of about 700 factories were discharged directly into the Nile River ${ }^{(43)}$. These industrial wastes that are released to surface or groundwater pose a major chemical threat. Such industrial liquid wastes are heavily contaminated with organic, heavy metals, corrosive, toxic or microbial loaded substances. Such water causes a major health problem ${ }^{(50)}$. Some groups of chemicals, such as carcinogenic, mutagenic compounds and neurotoxins are even unaffected by the common processes of water treatment. The threats imposed by these chemical discharges comprise: contamination of drinking water supplies, phyto- and aquatic toxicity, destruction of agriculture as well as fisheries, bioaccumulation, and biotransformation ${ }^{(9)}$. 
In Shoubra El Khaima Area (north of Cairo) huge volumes of untreated industrial wastewater are daily discharged into agricultural drains. The metal industry discharges almost $50 \%$ of total wastewater ${ }^{(51)}$.

The metropolitan area of Alexandria accommodates multiple industries near surface waters. For example, in El-Amiria at the Lake Mariut and near the ELMahmoudiya Canal are among such damage areas ${ }^{(9,51)}$. Alexandria is a major industrial center with 175 industries presenting about $25 \%$ of the total industries in Egypt. These industries include paper, metal, chemical, textile, plastic, pharmaceutical, oil and soap, and food processing ${ }^{(9,43)}$. The industries discharge their effluents mainly to Lake Mariut and EL-Mahmoudiya canal presenting a major source of marine pollution ${ }^{(9,51,52)}$.

In Egypt, food industry uses the largest volumes of water. It is responsible for more than $50 \%$ of the BOD load discharged to the Nile River by industrial plants ${ }^{(43)}$. At Upper Egypt, food industries are the major source of industrial pollution influencing Nile water quality. At Greater Cairo, about 82 chemical, textile and food industries contribute to the main load of total organic discharged effluents ${ }^{(9,42)}$.

\section{4. Pathogens (viruses and bacteria) :}

1.4.1.Fecal contamination of groundwater: The microbiological contamination of groundwater has profound and severe implications for public health. Contaminated groundwater can contribute to high morbidity and mortality rates from diarrheal diseases to epidemics. The use of inappropriate water supply and sanitation technologies leads to severe and long-term public health risks. Poorly constructed sewage treatment and land application of sewage can lead to groundwater contamination close to water supply sources. Recent studies have demonstrated that groundwater systems are increasingly vulnerable to microbial and chemical contamination, especially in developing countries ${ }^{(53)}$.

Microbiological, in particular virus survival in this environment is extended leading to increased public health risk ${ }^{(54)}$. Outbreaks of hepatitis, gastroenteritis and Norwalk virus dysentery have been attributed to groundwater contamination from septic tanks ${ }^{(55)}$. In Egypt, several studies showed contamination of groundwater $^{(56)}$, as well as, irrigation water by viruses ${ }^{(57)}$.

Several recent studies indicated that enteric bacteria of major importance, such as Salmonella and E. coli O157:H7, are hardy pathogens that can survive for a long period of time in mineral water ${ }^{(58)}$. Many studies showed possible contamination of groundwater with fecal coliforms (Escherichia coli) as affected by the use of treated wastewater for irrigation in Egypt. Retention of bacteria, by adsorption to soil organic matters, was demonstrated ${ }^{(59)}$. Studies conducted in different Egyptian villages showed bacterial contamination of groundwater with fecal coliforms through sewage ${ }^{(60-63)}$. At St. Katherine city, South Sinai, groundwater is heavily contaminated with domestic sewage. In a study conducted there, fecal indicators (fecal coliforms and fecal streptococci) were detected in different wells. The study indicated the presence of bacterial pathogens including Salmonella, Shigella and Vibrio in all wells ${ }^{(64)}$.

Egypt. J. Chem. 59, No.3 (2016) 
1.4.2. Soil bacteria : Mineral weathering by bacteria in groundwater aquifers has a significant impact. Although the role of fungi in mineral weathering is beginning to be elucidated, the relative impact of bacteria in this process and the molecular mechanisms involved remain poorly understood. To date a large range of bacterial strains or communities from diverse genera have been reported to be able to colonize mineral surfaces and/or to weather minerals, and for some of them a plant growth promoting effect was demonstrated. The demonstrated or hypothesized mechanisms used by bacteria to weather minerals include several oxide-reduction and dissolution reactions as well as the production of weathering agents, such as protons, organic acids and chelating molecules.

Soil microbes play an essential role in the environment by contributing to the release of key nutrients from primary minerals that are required not only for their own nutrition but also for that of plants ${ }^{(26)}$. In carbon cycle (Fig. 4), the Lime stones, carbonate weathering consists of two biological components, heterotrophic respiration from decomposers bacteria in soil and autotrophic respiration from plant roots, their symbiotic mycorrhizal fungi and rhizosphere bacteria ${ }^{(65)}$. Aside these biological sources, a minor abiotic fraction of the total soil $\mathrm{CO}_{2}$ efflux can be released during carbonate weathering and subsequent out gassing from soil water. Carbonate weathering is predominately controlled by water availability and $\mathrm{CO}_{2}$ partial pressure in the soil, at temperate temperature ${ }^{(66)}$. The succession of wet and dry periods can cause significant $\mathrm{CO}_{2}$ uptake and release due to carbonate dissolution and precipitation in arid and semi-arid environments ${ }^{(67)}$.

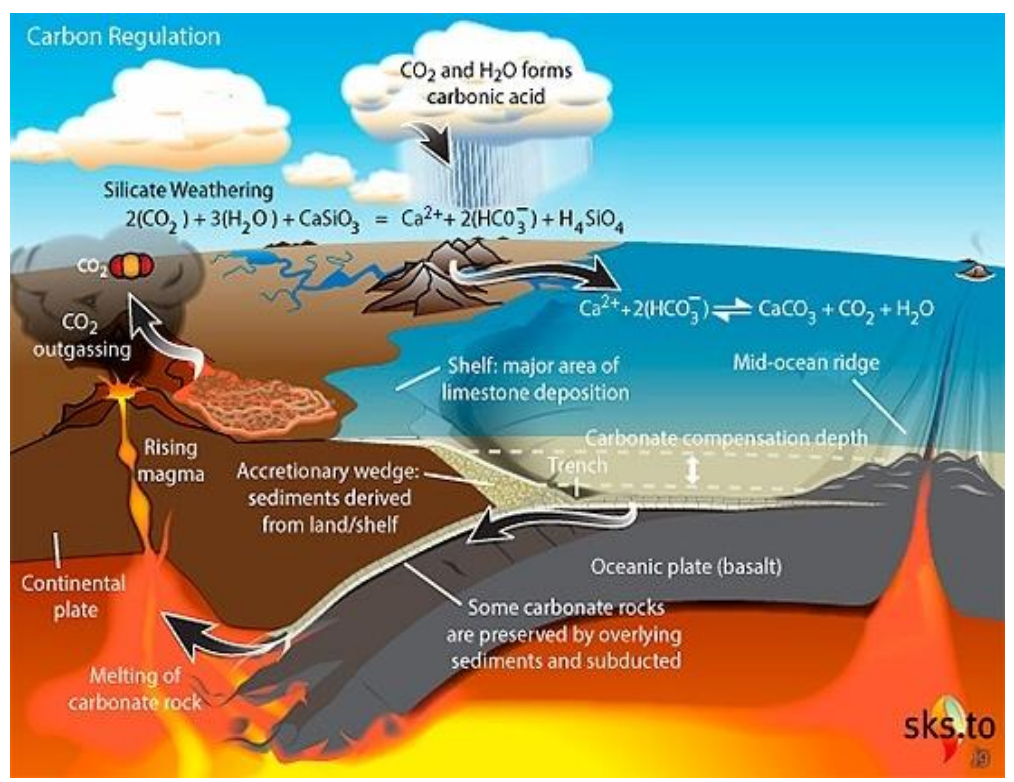

Fig. 4. Carbon Cycle: The Phanerozoic Carbon Cycle: $\mathrm{CO}_{2}$ and $\mathrm{O}_{2}$ (Berner, R.A., 2004). 
In addition to the carbon cycle, the nitrogen cycle (Fig. 5) is also of particular interest, as nitrogen availability can affect ecosystem processes including primary production and decomposition. Important processes in the nitrogen cycle include: nitrogen fixation, ammonification, nitrification and de-nitrification. Nitrogen fixation is conducted by symbiotic nitrogen-fixing bacteria such as Rhizobium, which convert gaseous nitrogen into ammonia and nitrogenous compounds which can be used by plants ${ }^{(68)}$. Ammonification or mineralization occurs when plants or animals die; bacteria or fungi convert the organic nitrogen within the dead wastes back into ammonium. Bacillus subtilis is an ammonifying bacterium converting nitrate via nitrite into ammonia, during anaerobic nitrate respiration $^{(69)}$. Nitrification is the conversion of ammonia to nitrate. It is performed primarily by soil-living bacteria and other nitrifying bacteria. In the primary stage of nitrification, the oxidation of ammonium is performed by bacteria such as Nitrosomonas species, which converts ammonia to nitrites. Other bacterial species, such as Nitrobacter, are responsible for the oxidation of nitrites into nitrates. Due to their very high solubility and because soils are largely unable to retain anions, nitrates can enter groundwater ${ }^{(68,70)}$. De-nitrification is the reduction of nitrates back into the inert nitrogen gas, completing the nitrogen cycle. The process is performed by bacterial species such as Pseudomonas and Clostridium in anaerobic conditions. They use nitrate as an electron acceptor in the place of oxygen during respiration ${ }^{(68)}$. Carbon and nitrogen cycles are given in Fig. 4 and 5, respectively.

Environment that are permanently anaerobic are more important in sulfate reduction, as in marine environments or salt marshes. Anaerobic decomposition through sulfate reduction by sulfate-reducing bacteria is well known in coastal marine sediments and salt marshes. Sulfide, resulting from sulfate reduction, serves in ferric ions reduction in soil and sediments ${ }^{(22,71)}$. Moreover, reduced sulfur compounds or sulfide, can support autotrophic bacterial fixation of $\mathrm{CO}_{2}$, as in the case of chemoautotrophic bacteria ${ }^{(71,72)}$.

Halophilic bacteria can affect the toxicity of heavy metals by the biotransformation processes, as high salt concentration is necessary for their growth $^{(52)}$. Mineral retention of bacteria in groundwater aquifers has a significant impact on groundwater contamination ${ }^{(73)}$. Hematite, quartz, and saprolite each harbored a community dominated by members of the division Proteobacteria as Pseudomonas species. However, the different substrata selected for different subdivisions of bacteria within the Proteobacteria. Mineralogical heterogeneity influences microbial community structure and diversity in pristine aquifers ${ }^{(74)}$. Versaphilic Anaeromyxobacter dehalogenans bacteria strains implicated in hexavalent uranium reduction and immobilization were isolated from the fractured saprolite subsurface environment ${ }^{(75)}$. In Ghana, weathering contributed significantly to groundwater salinity, hardness, toxic element and microbiological contamination $^{(76)}$. In Egypt, water contamination by halophilic bacteria was demonstrated in Mariut Lake Region ${ }^{(52)}$. 

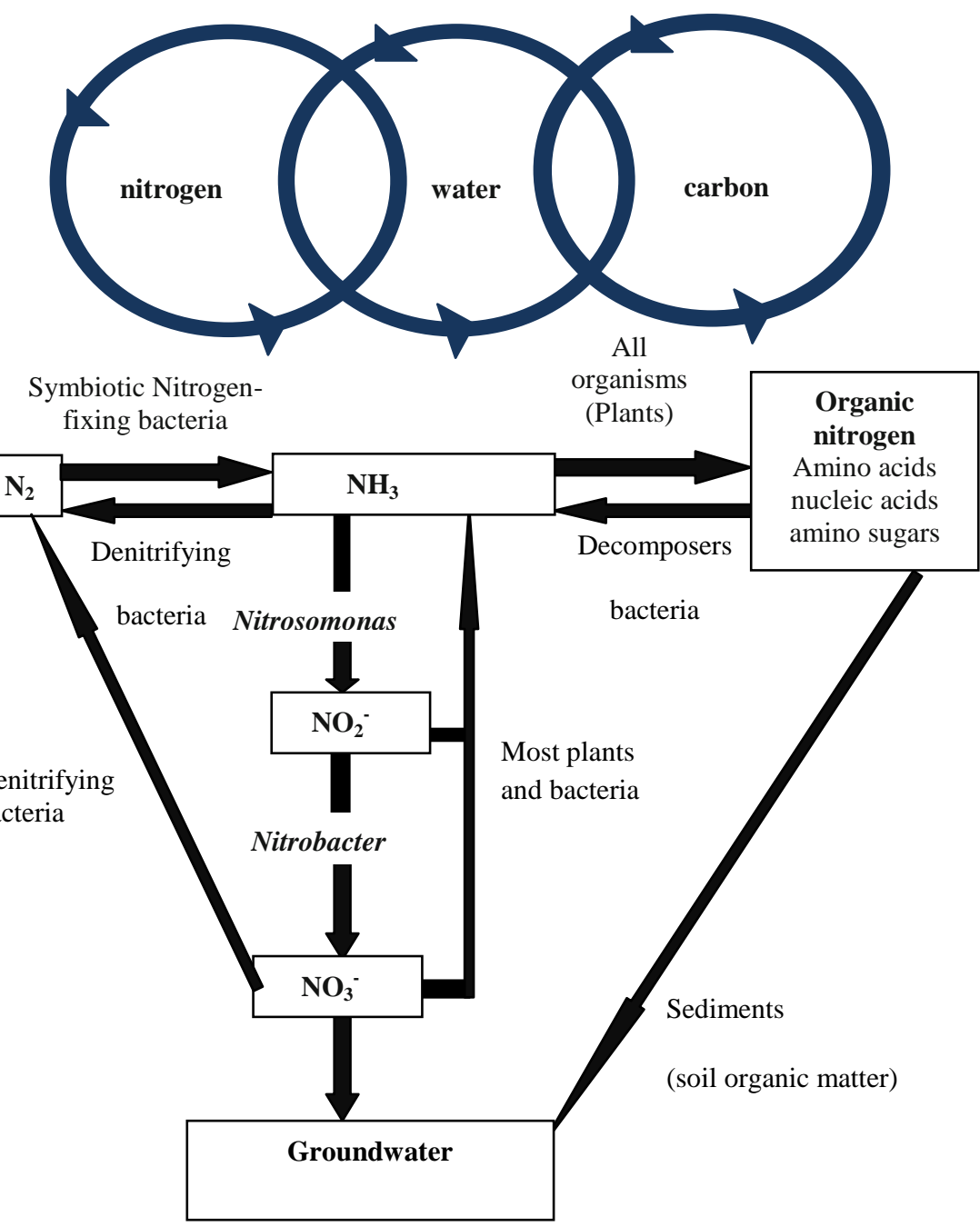

Fig. 5. Nitrogen cycle.

1.4.3.Mineral weathering effect on groundwater viral contamination : Virus stability is affected by adsorption to the weathered crystalline rock matrix at different $p \mathrm{H}$ conditions. Deeply weathered crystalline rock aquifer systems that comprise unconsolidated saprolite is derived from Precambrian gneiss and is underlying fractured bedrock (saprock), underlie $40 \%$ of sub-Saharan Africa. The vulnerability of this aquifer system to contamination remains poorly understood, particularly in rapidly urbanizing areas. In a study conducted in southeastern Uganda, bacteriophage adsorption to the weathered crystalline rock matrix was 
inferred and enabled by the low $p \mathrm{H}$ (5.7) of site groundwater, as bacteriophage has a relatively high isoelectric point $(\mathrm{pI}=6.6)^{(77)}$.

1. 5. Other contaminants : There are several other contaminants as: petroleum exploration and mining activities, abandoned well, over pumping, sea water intrusion as in Rafah Area and North Sinai ${ }^{(32,33)}$, animal wastes, seepage of fertilizers and pesticides, irrigation return-flow, natural leaching of solid waste and lakes infiltration ${ }^{(1)}$.

\section{Protection}

In many countries, the quality of water intended for human consumption is regulated through standards set at the regional, national or international level. For examples:

European Union Directive 98/83/EC on the quality of water intended for human consumption;

US EPA drinking water standards;

WHO Guidelines for Drinking Water Quality ${ }^{(28)}$, etc.

Other water uses, such as agricultural and landscape irrigation, urban and industrial uses, are not in some countries regulated under certain guidelines. However, regulations and/or guidelines have been established for wastewater reuse including WHO health related guidelines for the uses of wastewater in agriculture and aquaculture, US EPA guidelines for water reuse, Mediterranean Wastewater Reuse Report $^{(78)}$, and several national regulations and/or guidelines in the several Mediterranean countries such as: Egypt, Turkey, Syria, France, Italy, Spain and Tunisia.

As the population is continuously growing, entailing continuous increase in water demand and wastewater disposal, the water pumped for potable supply from rivers, lakes and even aquifers are more and more often polluted with wastewater. We learn every day from research findings and advances in analysis techniques that new micro-organisms, organic and inorganic trace elements are of concern for public health, most of them conveyed by wastewater. Then, potable water regulations have to be adapted to the progress of knowledge, but without imposing an unaffordable burden on less wealthy countries. Whatever the source, potable water quality should comply with the same regulations. However, the quality of water should be adapted to the source and to identify the harmful substances.

The different uses of water abstracted from aquifers that were recharged with recycled municipal water should be subjected to regulations or guidelines. The main aim of these guidelines is to avoid and reverse any significant and sustained degradation of aquifer water in terms of the quality and quantity. Though these guidelines are primarily intended to address diffuse pollution resulting from agricultural activity, they can be applied to artificial recharge. Such goals are targeted by the proposed State of California criteria for groundwater recharge ${ }^{(46)}$. Recharge projects must be designed in order not to jeopardize the public water supply systems including use of groundwater for potable water supply ${ }^{(40)}$.

Egypt. J. Chem. 59, No.3 (2016) 
A similar approach could be taken for aquifers that are not or will not be used to supply potable water because their water quality is too degraded. The most widespread example of such aquifers are the overexploited coastal aquifers invaded by seawater. Aquifers can be artificially recharged with recycled water to serve several water needs - agricultural and landscape irrigation, urban and industrial uses that do not require potable water quality. The recharge should be implemented in a way such that the groundwater quality is improved and meets on a long term basis the most stringent standards related to the intended water applications. Thus, a beneficial use of the groundwater is made possible; the recharge has improved the status of the aquifer.

Australian Water Quality Guidelines for Fresh and Marine Waters ${ }^{(79)}$, has accepted a differential protection policy. The level of protection offered at sites where recycled water is injected. This depends on the potential of environmental values of ambient groundwater and, therefore, on the current water quality ${ }^{(80)}$.

The status of the aquifer may not be the same in its whole extension. For instance, large coastal aquifers contain saline water near the shoreline and high quality fresh water inland. Also, different policies could be taken near the coastline and more inland. More inland, potable water can be extracted and a high quality water should be maintained. Whereas areas invaded by seawater can be recharged by lower water quality in order to accumulate water fit for irrigation. However, this sector-based management is only possible if the expansion of low water quality can be controlled.

\section{Exploitation and uses of groundwater in Egypt}

Masiyandima and Giordano ${ }^{(81)}$ provide a good overview on the exploitation of groundwater in Africa. Groundwater use in the Nile River basin includes: domestic water supply in rural and urban areas for drinking and household use, small commercial activities, industrial use and agricultural use for irrigation.

In Egypt, it is not surprising that groundwater is considered as an option for water supply in various uses. Currently, the total annual water requirement of all socioeconomic sectors in Egypt is estimated to be 76 billion $\mathrm{m}^{3} /$ year, of which the agriculture sector alone requires 85 percent $^{(9)}$. Groundwater use in agriculture in Egypt has a main impact. Around 25 to 30 percent of the total volume allocated to irrigation is thought to contribute to return flow and groundwater recharge via agricultural drainage and deep percolation ${ }^{(1)}$. A rise in water table results when irrigation-induced recharge is greater than the natural discharge. In many irrigated areas around the world, rising water tables have subsequently led to water logging and associated salinity problems to groundwater ${ }^{(82)}$.

In Egypt, there are several main projects for employing groundwater in agriculture as the famous "Toshka Project" in Western Desert. In this respect, the New Valley is the largest Egyptian irrigated agricultural development region that is solely dependent on groundwater resources ${ }^{(83)}$. At this region; and particularly, at west Nasser Lake, there are several development projects as "Toshka Project". 
The groundwater aquifers regions are subjected to over pumping to meet the overgrowing agricultural development in the area. As a result, continuous drop in groundwater level is observed. This is clear indication of the fact that the pumping from groundwater in these areas is much higher than the replacement rate to the aquifer. If the current groundwater extraction rate will continue in the future in the same manner, the groundwater chemistry in the areas is expected to become more saline. It is expected that the groundwater quality would be deteriorated due to the increase in the salt contents of the groundwater ${ }^{(5)}$.

The main reasons for limited use of groundwater, in Egypt, are: the hydrogeology, low yielding aquifers, the shortage of rainfall, the difficulties to access, great depth of water occurrence and contact or distance from surface water supplies $^{(3)}$. The deep and non-renewable fossil groundwater covers about 65 percent of $\mathrm{Egypt}^{(84)}$.

\section{Groundwater recharge}

Groundwater recharge has been used to prevent the decline in groundwater level and to preserve the groundwater resource for future use. Compared to conventional surface water storage, aquifer recharge has many advantages, such as negligible evaporation, little or no contamination by animals, and no algal blooming. Furthermore, it protects groundwater from saltwater intrusion by barrier formation in coastal regions, and controls or prevents land subsidence. It can also have positive effects on the overall water quality. Some projects may add water to saline aquifers. Adding fresh water to saline aquifers can lower salinity levels, as previously described. It is also less costly because no pipeline construction is required. Groundwater recharge with reclaimed water presents various health concerns when water is extracted from a well and used for irrigation or other purposes. As the performance of soil aquifer treatment is uneven depending on hydraulic loading, each project should be carefully designed and adequate attention should be paid to reduce pathogens ${ }^{(40,41)}$.

To ensure a high level of groundwater protection, levels of pollutants in treated wastewater must be reduced to safe levels as determined by the Integrated Pollution Prevention Control legislation ${ }^{(78)}$.

\section{Aquifer recharge}

When better sources are not available, groundwater recovered from aquifers recharged with recycled water can be an option for potable supply. This practice, even after a series of treatments have brought recycled water quality up to the most stringent potable water standards, might not be easily accepted by the public. Injecting this water then recovering it a few months later, blended with natural groundwater, is more likely to be accepted by consumers. Thus the aquifer serves as a storage and, also, as a psychological and aesthetic facilitator.

1.1. Types of aquifer recharge: There are two types of aquifer recharge by treated wastewater including:

Egypt. J. Chem. 59, No.3 (2016) 
1.1. 1 -Direct injection : In direct injection, treated wastewater is introduced directly into deeper aquifers through an injection well.

1.1. 2 -Indirect recharge : It involves the use of a recharge basin, large vadose zone, without restricting layers. Groundwater recharge types are shown in Fig. 6.

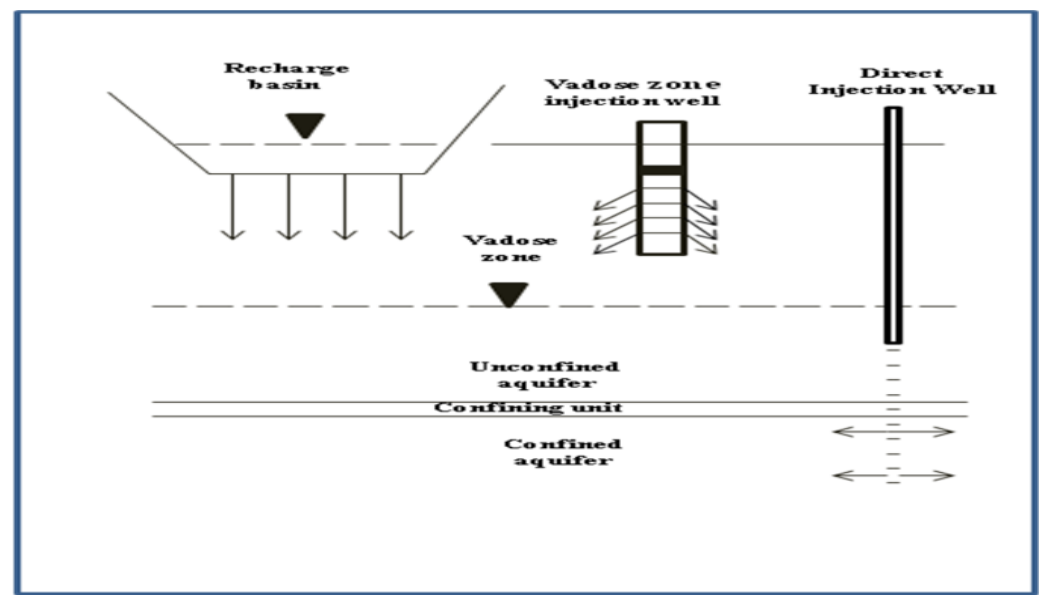

Fig. 6. Groundwater recharge types ${ }^{(46)}$.

\subsection{Advantages and disadvantages of groundwater recharge}

Direct injection : Direct injection of treated wastewater into well has different disadvantages. Sometimes, such wells are susceptible to clogging by suspended solids, biological activity or chemical impurities. This direct injection method requires advanced pretreatment of applied wastewater as additional disinfection. It is used usually in a well-confined aquifer.

Indirect recharge or vadose zone injection: It is an emerging technology that provides some of the advantages of both recharge basins and direct injection wells. This method is used when a permeable layer is not available at a shallow depth, and a recharge well has a relatively large diameter. Indirect recharge is feasible only for unconfined aquifers; the recharge water is spread on the land, over irrigation, or in infiltration basins and infiltrates through the vadose zone down to the water table. The unsaturated layer behaves as a filter and a natural reactor, providing an additional treatment and allowing the percolating water quality to greatly improve.

\section{Soil aquifer treatment}

Soil aquifer treatment provides the potential to recharge treated wastewater to groundwater, thereby supplementing fresh water supplies for irrigation and other purposes. Many contaminants in the effluent are thus removed by natural soil filtration $^{(40,41,46)}$. 
Simple treatment technology for handling the wastewater is a common practice before recharging the effluent into the ground. Among such simple technology is the artificial wetlands for wastewater treatment ${ }^{(85,86)}$. Combination of UASB and constructed wetlands as example of simple treatment technology is also employed for more effecient wastewater treatment before recharge ${ }^{(87)}$.

A major issue for the aquifer recharged with recycled water is the health risks that encountered when using the withdrawn water. The contaminants of concern are trace organic pollutants, microorganisms, heavy metals and nutrients. Risk impact is depending on the use and quality of the withdrawn water. Such issue of concern was addressed via health guidelines and regulations related to the different uses of water as well as the reuse of treated wastewater. The arising question is it justified or important to regulate the aquifer recharged with recycled water which is highly characterized (i.e. the characteristics of the recycled waters are beyond or highly treated).

Facotors affecting the quality of the aquifer waters are the following: (a) The method of recharge, (b) The quality of the recharged water, (c) The residence time of water, (d) The physical characteristics of the aquifer layers and the vadose zone, (e) The back history of the recharged aquifer, and (f) If the water was blended with other sources ${ }^{(40,46)}$. The issue is at which point should we implement the guidelines and/or regulations: at the point of withdrawal, at the point of use or the recycled water before recharge?

1.2. Aquifer recharge requirements : As it has been stated before, aquifer recharge, direct and indirect, of potable and non-potable aquifers should be considered.

1.2.A. Recharge requirement for indirect potable reuse : Artificial recharge for indirect potable reuse is an attractive option that has been considered for years and is implemented in several US states (West Basin and Orange County in California, and Arizona) ${ }^{(82)}$. The recharge should not degrade the quality of the groundwater nor impose any additional treatment after pumping. It seems, with the exception of Australia ${ }^{(88)}$, that the existing regulations do not rely on the capability of the aquifer to remove pollutants to meet the water quality required within the aquifer. In practice, the recharge water reaching the saturated zone of the aquifer should have previously acquired the quality admitted for drinking water.

If the recharge is direct, then the injected water should be potable, abiding, as a minimum requirement, by the regulations enforced in the country or by the WHO Guidelines for Drinking Water Quality (WHO, 2006). Moreover, the injected water should also be treated in order to prevent clogging around the injection wells, It has been reported that long term health risks linked to mineral and organic trace elements and the degradation of the injected water quality into the aquifer. The capacity of the aquifer to remove pollutants provides an additional barrier protecting the abstracted water quality ${ }^{(89)}$.

Egypt. J. Chem. 59, No.3 (2016) 
Setting requirements for indirect recharge is not an easy task. The quality of infiltrated water may be dramatically improved when percolating through the vadose zone, thanks to retention and oxidation processes. These processes affect organic matter, nutrients, micro-organisms, heavy metals and trace organic pollutants. However, though much has been learned on these processes during the past years ${ }^{(37-39,90)}$. On paper forecasting of the efficiency of the treatment provided by infiltration through a vadose zone and a lateral transfer in the saturated zone is hardly feasible. Performances depend on a number of factors such as: depth of the unsaturated zone, physical and mineralogical characteristic of the soil layers, heterogeneity, hydraulic load, infiltration schedule and infiltrated water quality.

Therefore, when transfer through the vadose zone is part of the treatment intended to bring injected water up to potable water quality, a case by case approach should be highly recommended. For each project, pollutant removal tests should be performed, at the laboratory and on site. Every category of pollutants of concern should be considered. The example of the Dan Project in Middle East shows that submitting secondary effluents to a SAT system in a dune sand aquifer can result in the production of a nearly potable water ${ }^{(91)}$. However, recharging potable water aquifer with secondary effluents through SAT would not be recommended; further treated water including microbial decontamination is suitable to obtain potable quality in the aquifer. Furthermore, relying on water transfer in the unsaturated zone to meet potable water quality would not be recommended in heterogeneous soils. In a drinking water treatment plants in Sinai, Egypt, it has been observed that the settled backwashing water of the Drinking Water Treatment Plant was injected in the ground sandy soil top-layer for the purpose of filtration and to form area of under groundwater. The resulted groundwater is characterized by reasonable quality as drinking water ${ }^{(92)}$.

1.2.B. Recharge requirement of non potable aquifers : The quality of the water extracted from the aquifer should meet the most stringent standards related to the intended water applications : irrigation, urban and industrial uses. Health related standards are those applying to wastewater reuse, where micro-organisms are the main concern. Limits can also be set for other parameters such as organic matter and heavy metal contents - when irrigation is considered. Trace organic elements are not likely to present major harmful impact. As mentioned for the case of potable aquifer recharge, it would not be recommended to rely on the saturated zone of aquifers for the improvement of the recharged water quality, even if there is no doubt that filtration effects do exist. The saturated zone should only be considered as an additional barrier.

When the recharge is direct, the recycled water should have been upgraded up to the standards and limits required for the intended applications. A high degree of treatment is also necessary to make the injection sustainable. Suspended solids and organic matter should have been drastically reduced to avoid clogging around the injection wells ${ }^{(40)}$. 
Indirect recharge requires a less treated injectant and is more easy to implement. SAT is an appropriate treatment to meet the required water quality, providing it is properly designed and managed. Prediction of the quality of the percolating water when it reaches the saturated zone is generally uneasy. The main reason is the high heterogeneity of soil layers. Therefore, a detailed investigation of the hydraulic characteristics of the soil layers below the infiltration site is of the utmost usefulness. On site performance tests are necessary. Dune sand layers, often homogeneous, are an exception. When highly permeable or heterogeneous on site soils are not able to provide the required treatment, infiltration percolation through calibrated sand beds filling pits excavated at the soil surface can be used as a treatment ${ }^{(39,93)}$.

The quality required of the recycled water applied in infiltration facilities should depend on the site, the hydraulic load, the infiltration schedule and the quality to be reached in the aquifer. A secondary treatment is a minimum. Each project must be tailored according to the local context and the water quality to be reached.

\section{Example of Balearic island regulation}

A recent draft of Spanish regulation on wastewater reuse set a few requirements on the water used for aquifer recharge. The indicators of injecting quality taken into account are nematode eggs, E. coli, total suspended solids (T.S.S.), turbidity and total nitrogen ${ }^{(94)}$. Artificial groundwater recharge by recycled treated wastewater had been earlier addressed in the recommendations for water reuse issued by the government of Balearic Islands, Spain in 1995. It constitutes one of the very few examples of such recommendations in Europe.

Renewable groundwater resources strategy Delta

The renewable groundwater aquifer strategy underlying the Nile Valley and

This strategy for groundwater envisages the conjunctive use of Nile surface and groundwater through the following:

- Using the aquifer as a storage reservoir to supplement surface water supply during peak periods and recharging during the minimum demand periods.

- The use of modern irrigation methods (sprinkler, trickle or drip) in the new lands that uses groundwater as the source of water to prevent water logging and keep the groundwater table far from the root zone.

- The use a vertical well drainage system in Upper Egypt to prevent the groundwater table from reaching the root zone thus avoiding water logging and increasing productivity.

- Groundwater could be used as a source of water for artificial fish ponds as it has a consistent and steady temperature and good quality.

- Augmentation of the canal water supply by pumping groundwater from low capacity private wells at tail ends of long distances where water shortage is experienced. 
1. Strategy in deep groundwater aquifers in the Western Desert and Sinai

Groundwater occurs at great depths in the western Desert. Thus, it needs a large investment to be profitable. Therefore future strategies to use groundwater in the Western desert and Sinai include:

- The use of the modern technologies to determine the main characteristics of each aquifer, its maximum capacity and safe yield. These data should be the basic criteria for selecting the most suitable projects that can use such aquifers as a sustainable source of water.

- New small communities $\left(2 \times 10^{3}\right.$ to $5 \times 10^{3}$ feddans equivalent to $0.84 \times 10^{3}$ to $2.1 \times 10^{3}$ hectares) in the desert areas designed to use all available natural resources through integrated planning.

- The Use of non-conventional sources of energy such as solar and wind to minimize the costs of pumping.

- The Use of new technologies for farm irrigation in desert areas to minimize field losses especially deep percolation due to the high porosity of such soils.

\section{Brackish groundwater desalination}

Desalination in Egypt started some 20 years ago for (additional) drinking water supply to coastal towns, in the petroleum sector and the energy sector (power stations). Due to the developments in desalination techniques and the reduction of the cost price, the application opportunities of desalination for fresh water production have sharply increased and will become even a more competitive option in the near future worldwide.

The main technologies for desalination are: multi-stage flash evaporation (MSF) and reverse osmosis (RO). Most of the old installations are evaporation plants. In recent years, a large number of RO plants and Evaporation distillation (ED) plants have become operational in different economic sector ${ }^{(95)}$. $\mathrm{RO}$ is currently the fastest growing technology and is applied not only for desalination of seawater but also for treatment of brackish water and to produce high quality production water for industrial use and even to treat domestic wastewater or drainage water. Recently, brackish water as well as certain industrial wastewater could be treated or valorized by successive membrane technology ${ }^{(96)}$.

Desalination of brackish groundwater in Egypt has a great potential with respect to the availability of the resource. All major aquifer systems in Egypt contain vast quantities of brackish groundwater. The exploitation of this resource is still limited. There are a number of reasons that explain this:

- Desalination has always had the label of being expensive

- Unfamiliarity with the operation of desalination plants for brackish water

- Unfamiliarity with the dynamics of brackish groundwater during exploitation (quality changes)

- Occurrence of brackish groundwater is in low demand areas

- Questions with respect to disposal of the brine (the hyper saline effluent). 
One of the areas of special interest is the Red Sea coastal area where large quantities of brackish groundwater are available from different aquifers. Part of this water occurs as springs or can be pumped at shallow depth ${ }^{(2)}$.

\section{A. Desalination techniques for groundwater reclamation :}

2.A.1. Membrane filtration technology: Membrane filtration has increasingly been utilized as an effective measure to obtain higher quality of water from wastewater and seawater. It is a process of separating materials based on their particle size and other compound properties by letting water through membranes using pressure and concentration.

Membrane filtrations are classified according to the size of materials removed:

- Microfiltration (MF) membrane has pores of 0.1-1 $\mu \mathrm{m}$ in diameter. It can remove particles and is effective against bacteria, cysts, and oocysts.

- Ultrafiltration (UF) membrane has smaller pores $(0.01-0.1 \mu \mathrm{m})$ and can remove particles and large molecules, including bacteria and viruses.

- Reverse Osmosis (RO) membrane can reject even smaller ionic solutes such as salts resulting in almost mineral-free water, based on sieving and electrochemical interaction between molecules and membrane.

- Nanofiltration (NF) membrane is similar to RO and its operation pressure and salt rejection rate are low.

The Reverse Osmosis system is increasingly used in dry regions, such as Saudi Arabia, Libya where there is a high demand for seawater desalination. The membrane system is also a promising technology. It can be used instead of large sedimentation pond or coagulation process using chemicals. In addition, filtering is compatible for removing bacteria and viruses ${ }^{(97)}$.

2.A.2. Membrane Bioreactor $(M B R)^{(98,99)}$ : It provides excellent effluent quality, suitable for reuse or recharge to groundwater, as membranes provide high removal of pathogens including bacteria, protozoa and viruses, resulting in excellent physical disinfection ${ }^{(100)}$. It has been documented also that the other pollutant parameters, such as nitrogenous compounds, phosphates and heavy metals, decreased to variable degrees ${ }^{(101-103)}$. It can efficiently replace the conventional treatment process. Another study showed that the use of this method decreased heavy metals but not to the sufficient degree ${ }^{(10)}$.

\section{Future overview}

Egypt as other Middle East countries is poor in rainfall. Sometimes, these countries are faced with seasonal and periodic droughts. Further, climate change predictions indicate that this situation may worsen. However, Egypt is considered very low in rainfall all over the year around in correlation to many African countries. Without the River Nile, Egypt could face a serious water income problem. Groundwater can provide a tool against this threat, supplementing surface water supplies and reducing risk of water shortages. There is a real danger of groundwater depletion, particularly in the shallow aquifer in some areas as Western Desert, Eastern Desert and Sinai.

Egypt. J. Chem. 59, No.3 (2016) 
Southwest Egypt is within the south western part of Dakhla basin, which, together with Kufra basin in Libya forms the well known Nubian Aquifer in Eastern Sahara. Water resources exploration in southwest Egypt is threatened with many problems. The most serious is the rapid depletion of groundwater. In fact, if the planned extraction of 1,200 million $\mathrm{m}^{3} / \mathrm{year}$ in East Oweinat area is imposed, drawdown after 100 years could be as much as $200 \mathrm{~m}$. By this time the cone of depression will extend to Dakhla and Kharga Oases ${ }^{(104)}$.

Two main land reclamation projects have been launched to form the base for population redistribution and further economic development. The first is the ElSalam Canal east of the Suez Canal and El-Sheikh Jaber east of the Suez Canal to reclaim about 620,000 feddans. The second project is the El-Sheikh Zayed Canal, which will reclaim some 540,000 feddans in the south of the New Valley ${ }^{(105)}$. The main constraint to implement these projects is the amount of available water. It is well known that the water resources in Egypt are limited to: a share of 55.5 $\mathrm{BCM} /$ year in the Nile river flow allocated for Egypt according to the Nile Water Agreement (1959), the deep groundwater in the deserts (mostly non-renewable), and a small amount of rainfall in the northern coastal area and Sinai.

Since 1996, groundwater development has started. The present use is concentrated in the Nile aquifer system, followed by the desert fringes and the Nubian sandstone. Other aquifer systems are still underdeveloped. Moreover, within the developed systems, only part of the potential is utilized mainly where ground water is rresh $^{(3)}$.

The Egyptian National Committee on Irrigation and Drainage, the Ministry of Water Resources and Irrigation ${ }^{(106)}$, has adopted a management plan which aims to enhance groundwater resources sustainability and to encourage agricultural development in desert areas. These areas would involve initiating new communities that can absorb part of the highly concentrated population in the Nile valley and Delta. Such approach will increase the future demands for groundwater, which consequently will need continuous monitoring and evaluation of the groundwater aquifers to avoid any possible deterioration in these aquifers due to misuse.

\section{Conclusion}

As ever more countries are experiencing water shortages, aquifer recharge with recycled water will become an essential component of water management strategies. Aquifers constitute inter-annual storage systems in which introduction of pollutants may have long term impacts. Therefore, avoiding groundwater jeopardy is a pre-requisite of any aquifer recharge project. Also, recharge should not lead to addition of supplementary treatments after withdrawal that would be necessary to meet the standards related to the intended water applications. 
Distinction between potable and non potable aquifers is essential and will allow for fostering the development of aquifer recharge and the saving of large amount of water resources. Essential distinction is also to be made between indirect (surface spreading) and direct (injection wells) recharge.

Several approaches, at the important exception of the Australia's one, assume that the ability of the saturated zone to improve water quality, whereas demonstrated, should not be taken into account when setting regulations. In this conservative approach, the transfer in the aquifer is considered as an additional barrier. As a result, when direct recharge is performed, the quality of the injected water should meet the quality required from the water which will be subsequently withdrawn from the aquifer. When aquifer water will be pumped and is going to be used for unrestricted irrigation, then the injected wastewater should meet the standards established for such purpose of irrigation.

With regard to indirect recharge, on the contrary, water quality improvement due to percolation through the unsaturated zone is taken into account. As this improvement varies with a number of factors, the recharge design should be tailored case by case, after in depth investigations and preliminary in situ tests.

Sector-based management of aquifers is to be taken into consideration, whenever appropriate and provided consistent monitoring programmes are implemented. The Balearic Islands recommendations are given as an example of Mediterranean attempt to address health related issues, not as a model.

Shallow groundwater aquifers, in particular in the Nile Delta, are often heavily contaminated. This groundwater could be contaminated with nitrogen, pesticide, herbicide and fertilizers as a result of the extensive use of these chemicals. Pesticide and herbicide are used to control weeds in canals.

Acknowledgement: The authors are in great debt to the facilities provided by the project titled "Sustainable Development for Wastewater Treatment and Reuse via Constructed Wetlands in Sinai (SWWTR)" that is funded by the Egyptian STDF.

\section{References}

1. Abdel-Shafy, H.I. and Mansour, M.S., Overview on water reuse in Egypt: Present and Future. Sustainable Sanitation Practice, 14, 17-25 (2013).

2. Allam, A.R., Saaf, E. and Dawoud, M.A., Desalination of brackish groundwater in Egypt. Desalination , 152, 19-26 (2003).

3. Elnashar, W.Y., Groundwater Management in Egypt. IOSR-J.M.C.E. 11, 69-78 (2014).

4. Wallick, E.I. and Toth, J., Methods of regional groundwater flow analysis with suggestions for the use of environmental isotopes. In : "Interpretation of Environmental Isotope and Hydrochemical Data in Groundwater Hydrology". Proceedings of an Advisory Group Meeting , 27-31 January 1975, International Atomic Energy Agency (IAEA), Vienna, Austria, pp. 37-64 (1976).

Egypt. J. Chem. 59, No.3 (2016) 
5. Abdel Moneim, A.A., Zaki, S. and Diab, M., Groundwater Conditions and the Geoenvironmental Impacts of the Recent Development in the South Eastern Part of the Western Desert of Egypt. Journal of Water Resource and Protection , 6, 381-401 (2014).

6. Taylor, R. and Howard, K., A tectono-geomorphic model of the hydrogeology of deeply weathered crystalline rock: Evidence from Uganda. Hydrogeology J. 8, 279294 (2000).

7. Phillips, D.H. and Watson, D.B., Distribution of uranium and thorium in dolomitic gravel fill and shale saprolite. J. Hazard. Mater, 285, 474-482 (2015).

8. NWRP, National Water Resources Plan for Egypt (NWRP) 2017. Policy Report: Water for the Future, Planning Sector, Ministry of Water Resources and Irrigation, Cairo, Egypt, pp. 211.223 (2005).

9. Abdel-Shafy, H.I. and Aly, R.O., Water Issue in Egypt: Resources, Pollution and Protection Endeavors. C.E.J.O.E.M. 8, 3-21 (2002).

10. Abdel-Shafy, H.I. and Abdel-Sabour, M.F., "Wastewater reuse for irrigation on the desert sandy soil of Egypt: long-term effect" In : "Integrated Urban Water Resources Management" P. Hlavinek, T. Kukharchyk, J. Marsalek \& I. Mahrikova (Ed). pp. 301312 . Springer, Netherlands (2006).

11. Abdel-Shafy, H.I., Sayed, S.A. and Yhaya-Omar, T.M., Risk assessment of sewage reuse on the sandy soil of the Abu-Rawash Desert, Egypt. Environ. Prot. Eng. 29, 5-19 (2003).

12. Abdel-Shafy, H.I., Guindi, Kh.A. and Tawfik, N.S., Groundwater contamination as affected by long-term sewage irrigation in Egypt". In : "Efficient Management of Wastewater" I. AL-Baz, R. Otterpohl \& C. Wendland (Ed.). pp. 53-63. Springer, Berlin Heidelberg (2008).

13. El-Sayed, M.H., Abo El-Fadl, M.M. and Shawky, H.A., Impact of hydrochemical processes on groundwater quality, Wadi Feiran, South Sinai, Egypt. Aust. J. Basic \& Appl. Sci. 6, 638-654 (2012).

14. Jacks, G., Chemistry of ground water in a district in Southern India. J. Hydrol. 18, 185-200 (1973)

15. Bartarya, S.K., Hydrochemistry and rock weathering in a sub-tropical Lesser Himalayan River basin in Kumaun, India. J. Hydrol. 146, 149-174 (1993).

16. Mackenzie, F.T. and Garrels, R.M., Silicates: Reactivity with sea water. Science, 150, 57-58 (1965).

17. Rajmohan, N. and Elango, L., Identification and evolution of hydrogeochemical processes in the groundwater environment in an area of the Palar and Cheyyar River Basins, Southern India. Environ. Geol. 46, 47-61 (2004). 
18. Kumar, M., Ramanathan, AL., Rao, M.S. and Kumar, B., Identification and evaluation of hydrogeochemical processes in the groundwater environment of Delhi, India. Environ. Geol. 50, 1025-1039 (2006).

19. Schuh, W.M. , Klinkebiel, D.L. , Gardner, J.C. and Meyer, R.F., Tracer and nitrate movement to groundwater in the Northern Great Plains. J. Environ. Qual. 26, 13351347 (1997)

20. FAO, World Reference Base for Soil Resources 2014, International soil classification system for naming soils and creating legends for soil maps. World Soil Resources Report No.106, Food and Agriculture Organization of the United Nations (FAO), Rome (2015). PDF ISBN: 978-92-5-108370-3

21. Ugolini, F.C. and Spaltenstein, H., Pedosphere In : "Global Biogeochemical Cycles" S.S. Butcher, R.J. Charlson, G.H. Orians \& G.V. Wolfe (Ed.). pp. 123-153 . Academic Press, London (1992).

22. Chapin III, F.S., Matson, P.A. and Vitousek, P.M., Geology, soils, and sediments. In : "Principles of Terrestrial Ecosystem Ecology" F.S. Chapin III, P.A. Matson \& P.M. Vitousek (Ed.), $2^{\text {nd }}$ ed., Springer, New York, USA, pp. 63-90, 473-509 (2011).

23. Waugh, D., Soils, Processes of soil formation, Podsolisation. In : Geography : An Integrated Approach" D. Waugh (Ed.), $3^{\text {rd }}$ ed., Nelson Thornes, Gloucester, U.K, pp. $272(2000)$.

24. Zambell, C.B., Adams, J.M., Gorring, M.L. and Schwartzman, D.W., Effect of lichen colonization on chemical weathering of hornblende granite as estimated by aqueous elemental flux. Chem. Geol. 291, 166-174 (2012).

25. Landeweert, R., Hoffland, E., Finlay, R.D., Kuyper, T.W. and van Breemen, N., Linking plants to rocks: ectomycorrhizal fungi mobilize nutrients from minerals. Trends Ecol. Evol. 16, 248-254 (2001).

26. Uroz, S., Calvaruso, C., Turpault, M.P. and Frey-Klett, P., Mineral weathering by bacteria: ecology, actors and mechanisms. Trends Microbiol. 17, 378-387 (2009).

27. Calvaruso, C., Turpault, M.P. and Frey-Klett, P., Root-associated bacteria contribute to mineral weathering and to mineral nutrition in trees: a budgeting analysis. Appl. Environ. Microbiol. 72, 1258-1266 (2006).

28. WHO, Guidelines for Drinking-Water Quality: "Health Criteria and Other Supporting Information", $2^{\text {nd }}$ ed., Volume 2. World Health Organization (WHO), Eastern Mediterranean Regional Office, Amman, Jordan, pp. 132-388 (1996).

29. WHO, Guidelines for Drinking-Water Quality, Third ed., Volume 1. World Health Organization (WHO), Geneva, pp. 296-493 (2004).

http://apps.who.int/iris/bitstream/10665/42852/1/9241546387.pdf

30. WHO, Guidelines for Drinking- Water Quality, Fourth ed. World Health Organization (WHO), Geneva, pp. 219-474 (2011). http://apps.who.int/iris/bitstream/10665/44584/1/9789241548151_eng.pdf

Egypt. J. Chem. 59, No.3 (2016) 
31. El Kashouty, M., El Sayed, E. and Kamel A.A., The hydrochemical characteristics and evolution of groundwater and surface water in the western part of the River Nile, El Minia district, Upper Egypt. Arab. J. Geosci. 5, 637-652 (2012).

32. El Alfy, M. and Merkel, B., Assessment of human impact on quaternary aquifers of Rafah Area, NE Sinai, Egypt. Int. J. Econ. \& Environ. Geol. 1, 1-9 (2010).

33. El Alfy, M., Hydrochemical modeling and assessment of groundwater contamination in Northwest Sinai, Egypt. Water Environ. Res. 85, 211-223 (2013).

34. Sharaky, A.M., Atta, S.A., El Hassanein, A.S. and Kallaf, K.M., Hydrogeochemistry of groundwater in the Western Nile Delta aquifers, Egypt. Proceedings of the $2^{\text {nd }}$ International Conference on the Geology of Tethys, Cairo University, Egypt, pp. 1-23 (March 2007).

35. Mohamed, R.F. and Hua, C.Z., Regional groundwater flow modeling in Western Nile Delta, Egypt. World Rural Observ. 2, 37-42 (2010).

36. Agrama, A.A. and El-Sayed, E.A., Assessing and mapping water quality (Case study: Western Delta-Egypt). I.W.T.J. 3, 158-169 (2013).

37. Bouwer, H., Issues in artificial recharge. Water Sci. Technol. 33, 381-390 (1996).

38. Drewes, J.E. and Jekel, M., Simulation of groundwater recharge with advanced treated wastewater. Water Sci. Technol. 33, 409-418 (1996).

39. Brissaud, F., Salgot, M., Bancole, A., Campos, C. and Folch, M., Residence time distribution and disinfection of secondary effluents by infiltration percolation. Water Sci. Technol. 40, 215-222 (1999).

40. Asano, T. and Cotruvo, J.A., Groundwater recharge with reclaimed municipal wastewater : Health and regulatory considerations. Water Res. 38, 1941-1951 (2004).

41. Missimer, T.M., Drewes, J.E., Maliva, R.G. and Amy, G., Aquifer recharge and recovery: Groundwater recharge systems for treatment, storage and water reclamation. Ground Water, 49, 771 (2011).

42. Harris, J., Brown, P.E. and Abdel Nasser, G., "Assessment of Water Quality Hazards in Egypt", National Water Quality Conservation Unit, PRIDE, USAID, Washington, DC, p.I-1_A-21 (1995).

43. Abdel-Shafy, H.I. and Aly, R.O., Wastewater management in Egypt. In : "Wastewater Reuse - Risk Assessment, Decision-Making and Environmental Security" M. K. Zaidi (Ed.). pp. 375-382. Springer, Netherlands (2007).

44. Tanji, K.K. and Kielen, N.C., "Water quality concerns in drainage water management, Toxic trace elements". In : "Agricultural Drainage Water Management in Arid and Semi-arid Areas" K. K. Tanji \& N. C. Kielen (Ed.), pp. 40. FAO irrigation and drainage paper No.61, Food and Agriculture Organisation of The United Nations, Rome, Italy (2002). 
45. Armanuos, A.M., Negm A. and Saavedra Valeriano, O.C., Grounwater quality investigation using water quality index and ARCGIS: Case study: Western Nile Delta aquifer, Egypt. Proceedings of Eighteenth International Water Technology Conference, IWTC18, Sharm El Sheikh, pp. 1-10 (March 2015).

46. EPA, Guidelines for Water Reuse. U.S. Environmental Protection Agency and U.S. Agency for International Development, Camp Dresser \& McKee, Inc., Washington, DC, pp.1-438 (2004). EPA number: EPA/625/R-04/108.

47. Farahat, E. and Linderholm, H.W., The effect of long-term wastewater irrigation on accumulation and transfer of heavy metals in Cupressus sempervirens leaves and adjacent soils. Sci. Total Environ. 512-513, 1-7 (2015).

48. Abdel-Kader, A.M. and Abdel-Rassoul, S.M., Prospects of water conservation in Egypt (Special reference to wastewater reuse). Proceedings of the Fourteenth International Water Technology Conference, IWTC 14 2010, Cairo, Egypt, pp. 519526 (2010).

49. UNEP-United Nations Environment Programme, "Evaluation of the industry and environment programme" H. Brezet \& F. Schelleman (Ed.) United Nations Environment Programme (UNEP), Nairobi, pp. 1-47 (1995). Accession code: Na. 958223270396.

50. Salem, H.M., Eweida, E.A. and Farag, A., "Heavy Metals in Drinking Water and their Environmental Impact on Human Health". ICEHM 2000, Cairo University, Egypt, pp. 542- 556 (September 2000).

51. El Ramly, I.M., Hydrogeological and water quality characteristics of the saturated zone beneath the various land uses in the Nile Delta region, Egypt. Proceedings of Rabat Symposium S4: Freshwater Contamination, IAHS Publ. No. 243, pp. 255-261 (April-May 1997).

52. Osman, O., Tanguichi, H., Ikeda, K., Park, P., Tanabe-Hosoi, S. and Nagata, S., Copper-resistant halophilic bacterium isolated from the polluted Maruit Lake, Egypt. J. Appl. Microbiol. 108, 1459-1470 (2010).

53. Colwell, R.R., Huq, A., Islam, M.S., Aziz, K.M., Yunus, M., Khan, N.H., Mahmud, A., Sack, R.B., Nair, G.B., Chakraborty, J., Sack, D.A. and RussekCohen, E., Reduction of cholera in Bangladeshi villages by simple filtration. Proc. Natl. Acad. Sci. U. S. A. 100, 1051-1055 (2003).

54. Pedley, S. and Howard, G., The public health implications of microbiological contamination of groundwater. Quart. J. Eng. Geol. 30, 179-188 (1997).

55. Yates, M.V., Yates, S.R. and Gerba, C.P., Modeling microbial fate in the subsurface environment. Crit. Rev. Environ. Contr. 17, 307-344 (1988).

56. Abd El Galil, K.H., El Sokkary, M.A., Kheira, S.M., Salazar, A.M., Yates, M.V., Chen, W. and Mulchandani, A., combined immunomagnetic separation-molecular beacon-reverse transcription-PCR assay for detection of hepatitis A virus from environmental samples. Appl. Environ. Microbiol. 70, 4371-4374 (2004).

Egypt. J. Chem. 59, No.3 (2016) 
57. El-Senousy, W.M., Costafreda, M.I., Pintó, R.M. and Bosch, A., Method validation for norovirus detection in naturally contaminated irrigation water and fresh produce. Int. J. Food Microbiol. 167, 74-79 (2013).

58. Leclerc, H., "Relationships between common water bacteria and pathogens in drinking-water". In : "WHO 2003: Heterotrophic Plate Counts and Drinking-water Safety, The Significance of HPCs for Water Quality and Human Health" J. Bartram, J. Cotruvo, M. Exner, C. Fricker \& A. Glasmacher (Ed.). pp. 80-118. IWA Publishing, London, UK, (2003).

59. Smith, E. and Hegazy, S.E., Coli transport in soil columns: implications for reuse of treated wastewater in irrigation. Water Sci. Technol. 54, 175-182 (2006).

60. Mostafa, A.H., Al-Wasify, R.S., Sayed, A.M. and Haroun, B.M., Microbiological and physicochemical evaluation of groundwater in Egypt. International Journal of Environment and Sustainability, 2, 1-10 (2013).

61. El Attar, L., Abdel Gawad, A., Khairy, A.E. and El Sebaie, O., The sanitary condition of rural drinking water in a Nile Delta Village. II. Bacterial contamination of drinking water in a Nile Delta village. J. Hyg. (lond) , 88, 63-67 (1982).

62. Shamrukh, M. and Khalif, A., Biological contamination of handpump ground water from sewage room in Upper Egypt. Proceedings of the $2^{\text {nd }}$ International Conference on Civil Engineering (ICCE-II), Faculty of Engineering-Mataria, Helwan University, Cairo, Egypt, pp. 525-530 (April 2000).

63. Abdel-Lah, A.K. and Shamrukh, M., Impact of septic system on ground water quality In A Nile Valley Village, Egypt. Proceedings of the Sixth International Water Technology Journal, IWTC 2001, Alexandria, Egypt, pp. 237-245 (2001).

64. Abdulla, H., Ghodeif, K., El-Shatoury, S. and Dewedar, A., Potential contamination of groundwater in the World Heritage Site of the St. Katherine Protectorate, Egypt. Egypt. J. Biol., 5, 1-9 (2003).

65. Högberg, P. , Nordgren, A., Buchmann, N., Taylor, A. F., Ekblad, A., Högberg, M.N., Nyberg, G., Ottoson-Lövenius, M. and Read, D.J., Large-scale forest girdling shows that current photosynthesis drives soil respiration. Nature, 411, 789-792 (2001).

66. Schindlbacher, A., Borken, W., Djukic, I., Brandstätter, C., Spötl, C. and Wanek, W. Contribution of carbonate weathering to the $\mathrm{CO}_{2}$ efflux from temperate forest soils. Biogeochemistry, 124, 273-290 (2015).

67. Serrano-Ortiz, P., Roland, M., Sanchez-Moral, S., Janssens, I.A. , Domingo, F., Goddéris, Y. and Kowalski, A.S., Hidden, abiotic $\mathrm{CO}_{2}$ flows and gaseous reservoirs in the terrestrial carbon cycle: review and perspectives. Agric. For. Meteorol. 150, 321-329 (2010).

68. Jetten, M.S., The microbial nitrogen cycle. Environ. Microbiol. 10, 2903-2909 (2008). 
69. Hoffmann, T., Frankenberg, N., Marino, M. and Jahn, D., Ammonification in Bacillus subtilis utilizing dissimilatory nitrite reductase is dependent on resDE. J. Bacteriol. 180, 186-189 (1998).

70. Vitousek, P.M., Aber, J.D., Howarth, R.W., Likens, G.E., Matson, P.A., Schindler, D.W., Schlesinger, W.H. and Tilman, D.G., Human alteration of the global nitrogen cycle: sources and consequences. Ecol. Appl. 7, 737-750 (1997).

71. Howarth, R.W., The ecological significance of sulfur in the energy dynamics of salt marsh and coastal marine sediments. Biogeochemistry, 1, 5-27 (1984).

72. Nelson, D.C. and Jannasch, H.W., Chemoautotrophic growth of a marine Beggiatoa in sulfide-gradient cultures. Arch. Microbiol. 136, 262-269 (1983).

73. Mills, A.L., Herman, J.S., Hornberger, G.M. and DeJESUS, T.H., Effect of solution ionic strength and iron coatings on mineral grains on the sorption of bacterial cells to quartz sand. Appl. Environ. Microbiol. 60, 3300-3306 (1994).

74. Boyd, E.S., Cummings, D.E. and Geesey, G.G., Mineralogy influences structure and diversity of bacterial communities associated with geological substrata in a Pristine aquifer. Microb. Ecol. 54, 170-182 (2007).

75. Thomas, S.H., Padilla-Crespo, E., Jardine, P.M., Sanford, R.A. and Löffler, F.E., Diversity and distribution of anaeromyxobacter strains in a uranium-contaminated subsurface environment with a nonuniform groundwater flow. Appl. Environ. Microbiol. 75, 3679-3687 (2009).

76. Affum, A.O., Osae, S.D., Nyarko, B.J., Afful, S., Fianko, J.R., Akiti, T.T., Adomako, D., Acquaah, S.O., Dorleku, M., Antoh, E., Barnes, F. and Affum, E.A., Total coliforms, arsenic and cadmium exposure through drinking water in the Western Region of Ghana: application of multivariate statistical technique to groundwater quality. Environ. Monit. Assess. 187, 1-23 (2015).

77. Taylor, R., Tindimugaya, C., Barker, J., Macdonald, D. and Kulabako, R., Convergent radial tracing of viral and solute transport in gneiss saprolite. Ground Water, 48, 284-294 (2010).

78. MED WWR WG, Mediterranean Wastewater Reuse Report. Append ix6: The Existing Eu Legal Framework on The Environment, Mediterranean Wastewater Reuse Working Group (MED WWR WG), pp. 32-38 (2007).

http://www.emwis.net/topics/ WaterReuse/ Final_report.doc (Last accessed 15 December 2015).

79. ANZECC and ARMCANZ, Australian and New Zealand guidelines for fresh and marine water quality, national water quality management strategy: The guidelines. paper No. 4, volume 1, the Australian and New Zealand Environment and Conservation Council and the Agriculture and Resource Management Council of Australia and New Zealand, CANBERRA, Australia, pp. 1-1_R7-3 (2000). https://www.environment.gov.au/system/files/resources/53cda9ea-7ec2-49d4-af29d1dde09e96ef/files/nwqms-guidelines-4-vol1.pdf (last accessed 17 December 2015) 
80. Dillon, P., Water recycling via managed aquifer recharge in Australia. Boletín Geológico y Minero, 120, 121-130 (2009).

81. Masiyandima, M. and Giordano, M.F., Sub-Saharan Africa: opportunistic exploitation. In: "The Agricutural Groundwater Revolution: Opportunities and Threats to Development" M. Giordano \& K.G. Villholth (Ed.) pp. 79-99 . CABI, Wallingford, UK (2007).

82. Tanji, K.K., Iqbal, M.M., Quek, A.F., Van De Pol, R.M., Wagenet, L.P., Fujii, R., Schnagl, R.J. and Prewitt, D.A., Surface irrigation return flows vary. California Agriculture , 31, 30-31 (1977).

83. Idris, H. and Nour, S., Present groundwater status in egypt and the environmental impacts. Environ. Geol. Water. Sci. 16, 171-177 (1990).

84. Maliva, R. and Missimer, T., Non-renewable groundwater resources. In : "Arid Lands Water Evaluation and Management" R. Maliva \& T. Missimer (Ed.), Environmental Science and Engineering Series, Springer, Berlin, Heidelberg, pp.927-951 (2012).

85. Masi, F., El Hamouri, B., Abdel Shafy, H., Baban, A., Ghrabi, A. and Regelsberger, M., Treatment of segregated black/grey domestic wastewater using constructed wetlands in the Mediterranean basin: the zer0-m experience. Water Sci. Technol. 61, 97-105 (2010).doi:10.2166/wst.2010.780

86. Abdel-Shafy, H.I. and Al-Sulaiman, A.M., Efficiency of degreasing/settling tank followed by constructed wetland for greywater treatment. Egypt. J. Chem. 57, 435-446 (2014).

87. Abdel-Shafy, H.I., El-Khateeb, M.A., Regelsberger, M., El-Sheikh, R. and Shehata, M., Integrated system for the treatment of blackwater and greywater via UASB and constructed wetland in Egypt. Desalination Water Treat. 8, 272-278 (2009).

88. ANZECC and ARMCANZ, Guidelines for Groundwater Protection in Australia, National Water Quality Management Strategy, the Australian and New Zealand Environment and Conservation Council and the Agriculture and Resource Management Council of Australia and New Zealand, CANBERRA, Australia, pp.1-88 (1995). http://www.environment.gov.au/system/files/resources/4d08becb-c90a-4637-bcbc5772451f7c5e/files/nwmqs-groundwater-guidelines. pdf (last accessed 17 December 2015)

89. WHO, Guidelines For Drinking-Water Quality, First Addendum to Third ed., Volume 1 Recommondations. World Health Organization, Geneva (WHO), pp.48-83 (2006). http://apps.who.int/water_sanitation_health/dwq/gdwq0506.pdf

90. Hassan, S.S., Abdel-Shafy, H.I. and Mansour, M.S., Removal of pharmaceuticals compounds from urine via chemical coagulation by green synthesized $\mathrm{ZnO}$ nanoparticles followed by microfiltration for safe reuse. Arab. J. Chem. (2016). doi: http://dx.doi.org/10.1016/j.arabjc. 2016.04.009.

91. Lazarova, V., Levine, B., Sack, J., Cirelli, G., Jeffrey, P., Muntau, H., Salgot, M. and Brissaud, F., Role of water reuse for enhancing integrated water management in Europe and Mediterranean countries. Water Sci. Technol., 43, 25-33 (2001). 
92. Abdel-Shafy, H.I., Salem, M.A., Mansour, M.S., El-Khateeb, M.A. and Abdel-Shafy, S.H., Drinking Water issue in North-West Sinai case study: The problem and solution in a case study. Egyptian J. Chemistry, 59, 2, pp.(2016)

93. Abdel-Shafy, H.I., El-Khateeb, M.A. and Shehata, M., Greywater treatment using different designs of sand filters. Desalination Water Treat., 52, 5237-5242 (2013).

94. Ortega, E. and Iglesias, R., Reuse of treated municipal wastewater effluents in Spain: Regulations and most common technologies, including extensive treatments. Desalination Water Treat., 4, 148-160 (2009).

95. Mezher, T., Fath, H., Abbas, Z. and Khaled, A., Techno-economic assessment and environmental impacts of desalination technologies. Desalination, 266, 263-273 (2011).

96. Abdel-Shafy, H.I., Schories, G., Mansour, M.S. and Bordei, V., Integrated Membrane System for the Recovery and Concentration of Antioxidant from Olive Mill Wastewater. Desalination Water Treat. 56, 305-314 (2015).

DOI:10.1080/19443994.2014.935807, http://dx.doi.org/10.1080/19443994.2014.935807.

97. UNEP-United Nations Environment Programme and Global Environment Centre Foundation "Water and Wastewater Reuse: An Environmentally Sound Approach for Sustainable Urban Water Management" C. Aoki, M.A. Memon \& H. Mabuchi (Ed.) UNEP-United Nations Environment Programme, Japan, pp. 12 (2005). Stock Number: DTI/0625/PA

98. Diagger, G.T., Rittmann, B.E., Adham, S. and Androettola, G., Are membrabe bioreactors ready for widespread application? Environ. Sci. Technol. 39, 399A-406A (2005).

99. Abdel-Shafy, H.I., Al-Sulaiman, A.M. and Mansour, M.S., Anaerobic/aerobic treatment of greywater via UASB and MBR for unrestricted reuse. Water Sci. Technol. 71, 630-637 (2015).

100. Abdel-Shafy, H.I. and El-Khateeb, M.A., Membrane bioreactor for the treatment of municipal blackwater in Egypt. Desalination Water Treat., 29, 56-62 (2011).

101. Abdel-Shafy, H.I., Hegemann, W., Guindi, Kh.A., Tawfik, N.S. and Teschner, K., Membrane Bioreactor for the Treatment of Wastewater in an Egyptian Plant. Central European J. of Occupational \& Environ. Medicine 11, 217-223 (2005).

102. Dialynas, E. and Diamadopoulos, E., Integration of a membrane bioreactor coupled with reverse osmosis for advanced treatment of municipal wastewater. Desalination, 238, 302-311(2009).

103. Schier, W., Frechen, F.B. and Fischer, St., Efficiency of mechanical pre-treatment on European MBR plants. Desalination, 236, 85-93 (2009).

104. Ebraheem, A.M., Riad, S., Wycisk, P. and Seif El-Nasr, A.M., Simulation of impact of present and future groundwater extraction from the non-replenished Nubian Sandstone aquifer in southwest Egypt. Environ. Geol. 43, 188-196 (2002).

Egypt. J. Chem. 59, No.3 (2016) 
105. Sallam, O.M., El Shewy, M.A. and Dawoud, M.A., New reclamation mega projects and increasing the pressure on water system in the Nile Valley and Delta in Egypt. Proceedings of WSTA $11^{\text {th }}$ Gulf Water Conference "Water in the GCC..Towards Efficient Management", Muscat, Sultanate of Oman, pp. 37-48 (October 2014).

106. MWRI/USAID, Policies and procedures for improved urban wastewater discharge and reuse. Appendix 3: Wastewater Irrigation for Forest Plantation. Report No.34, Egyptian Ministry of Water Resources and Irrigation and US Agency for International Development/Egypt, pp.6-48_6-60 (2000). http://pdf.usaid.gov/pdf_docs/Pnacs 687.pdf (last accessed 5 December 2015).

(Received 22/12/2015;

accepted $9 / 5 / 2016$ ) 


\section{المياة الجوفية فى مصر : مصادرها ، أماكن تواجدها ، كمياتها ،}

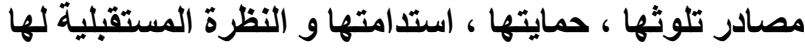

\section{حسين ابراهيم عبد الثافى و عزيزة هسن وجية كاله} قسم بحوث المياه و التلوث ـ المركز القومى للبحوث ـ ـ القاهرة ـ مصر . .

يتناول هذا المرجع الأوجة المختلفة ليصادر المياة الجوفية بمصر. تعتبر المياة

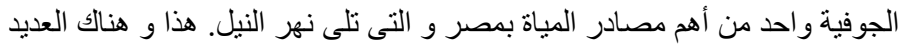

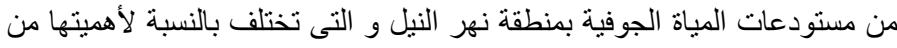

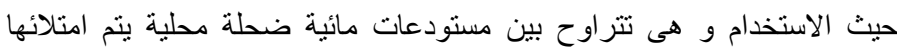

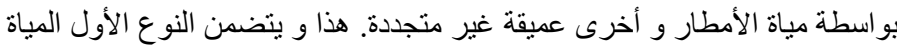

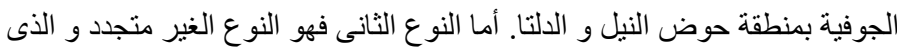

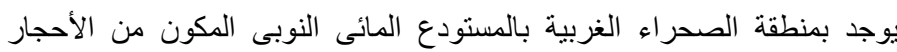

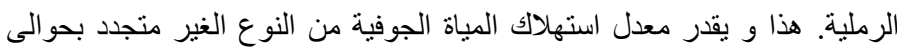

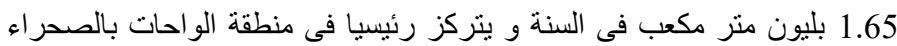

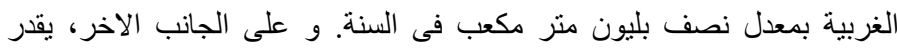

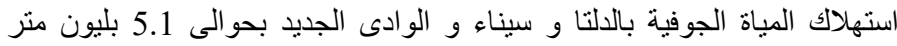

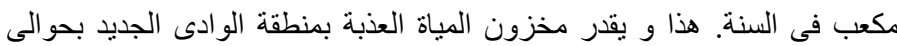

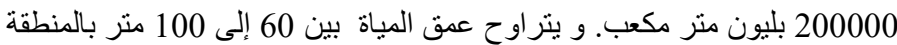

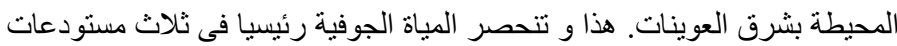

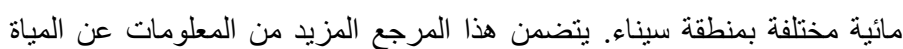

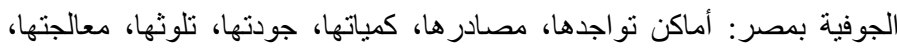
حمايتها و أخير الستخدامهاو كذا النظرة المستقلية لهاو و ملخص الأستنتاج. 